Check for updates

Cite this: Mater. Adv., 2021, 2,3234

Received 11th March 2021 Accepted 27th April 2021

DOI: 10.1039/d1ma00216c

rsc.li/materials-advances

\section{Technologies of lithium recycling from waste lithium ion batteries: a review $\dagger$}

\begin{abstract}
Hyuntae Bae ${ }^{a}$ and Youngsik Kim (D)*ab
The consumption of lithium-based materials has more than doubled in eight years due to the recent surge in demand for lithium applications as lithium ion batteries. The lithium-ion battery market has grown steadily every year and currently reaches a market size of $\$ 40$ billion. Lithium, which is the core material for the lithium-ion battery industry, is now being extracted from natural minerals and brines, but the processes are complex and consume a large amount of energy. In addition, lithium consumption has increased by 18\% from 2018 to 2019, and it can be predicted that the depletion of lithium is imminent with limited lithium reserves. This has led to the development of technologies to recycle lithium from lithium-ion batteries. This article focuses on the technologies that can recycle lithium compounds from waste lithium-ion batteries according to their individual stages and methods. The stages are divided into the pre-treatment stage and lithium extraction stage, while the latter is divided into three main methods: pyrometallurgy, hydrometallurgy, and electrochemical extraction. Processes, advantages, disadvantages, lithium extraction efficiency, price, environmental pollution and the degree of commercialization of each method are compared and analyzed quantitatively. Despite the growing attention and the development of various lithium recycling technologies, less than 1 percent of lithium is recycled currently. We propose future needs to improve the recycling technologies from waste lithium materials and hope that this article can stimulate further interest and development in lithium recycling.
\end{abstract}

${ }^{a}$ School of Energy and Chemical Engineering, Ulsan National Institute of Science and Technology (UNIST), Unist-gil 50, Ulsan, 44919, Republic of Korea

${ }^{b}$ Energy Materials and Devices Lab, 4TOONE Corporation, UNIST-gil 50, Ulsan, 44919, Republic of Korea

$\dagger$ Electronic supplementary information (ESI) available. See DOI: 10.1039/d1ma00216c

\section{Introduction}

Discussions regarding lithium-based technology have dominated the field of energy research in recent years. From the first commercialization in 1991, the lithium-ion battery has

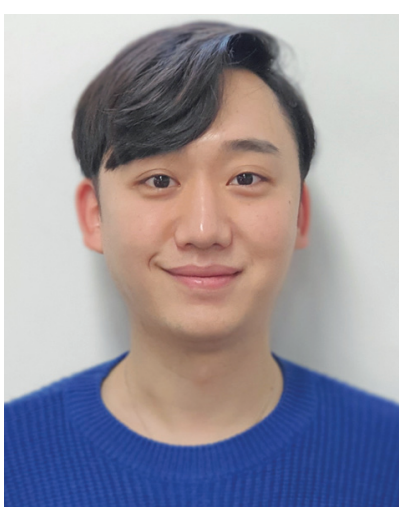

Hyuntae Bae graduated with a BS in chemistry from Gyeongsang National University 2014. In 2014, he joined the group of Prof. Youngsik Kim at the Ulsan National Institute of Science and Technology (UNIST), where his research currently focuses on recycling lithium from the waste lithium-ion batteries.
Hyuntae Bae

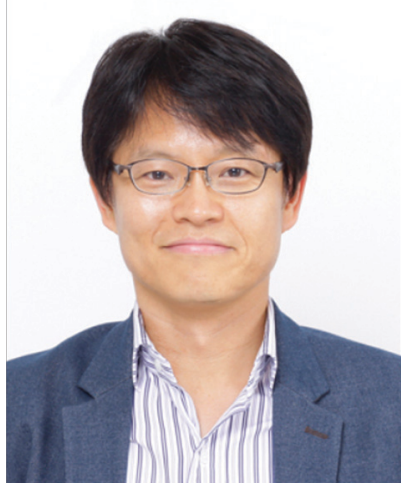

Youngsik Kim
Youngsik Kim is a professor at School of Energy and Chemical Engineering at Ulsan National Institute of Science \& Technology (UNIST). He received his PhD (2006, advisor: Prof. Steve W. Martin) in Materials Science and Engineering from Iowa State University. After, he joined Prof. John B. Goodenough's group at The University of Texas at Austin as a post-doctoral fellow. He conducted research in areas including lithium- and sodiumion batteries. Particularly, he is an inventor of the 'sea-water battery', which is developed as an alternative option for grid-scale energy storage. He is also the CEO of energy solution company, 4TOONE Corporation. 
been a core energy technology and it has been continuously researched for several decades for the development of the future energy market. ${ }^{1-7}$ Lithium is attracting attention as it is a key element of lithium-ion batteries. However, lithium is not evenly distributed around the world and is a limited element. Furthermore, with the rapid development of electric vehicle (EV) and energy storage system (ESS) technologies, the demand for lithium is rapidly increasing. Lithium consumption has more than doubled over the last decade. ${ }^{8,9}$ With a continuous consumption increase of lithium, our future energy market will suffer tremendous damage.

For these reasons, lithium is expected to become more valuable, highlighting the importance of lithium recycling. This paper explains the current state of lithium and emphasizes the importance of lithium recycling. In addition, this paper lists the various techniques used for lithium recycling, along with the process, advantages, and drawbacks of each method and concludes with recommendations for research and development in lithium recycling technologies.

\section{Current state of lithium}

\subsection{Lithium usage}

In $2011,30 \%$ of the lithium consumption was for ceramics and glass, followed by batteries and greases/castings. ${ }^{10,11}$ However, the application of batteries to small electronics such as smartphones and laptops, as well as larger systems such as electric vehicles (EVs) and energy storage systems (ESS), has caused 60\% of the lithium consumption to be associated with batteries ${ }^{12}$ (Fig. 1a).

Lithium is preferred as the material for batteries owing to three properties: (1) it is the lightest metal (2) it has the highest electrochemical potential of all metals, and (3) it has the highest energy density among all metals. ${ }^{13}$ In addition to batteries, lithium is also used in ceramics, glass, and greases/castings with particular chemical properties. Adding lithium to ceramics increases the glass melt rate and decreases their viscosity and melt temperature. Additionally, the high thermal expansion coefficient of lithium makes ceramics resilient to heat shock and increases mechanical strength. ${ }^{14}$ Lithium grease is useful in concentrating oil to produce high-temperature grease, ${ }^{15}$ and lithium additives are used in casting to increase fluidity. ${ }^{16}$ Organic lithium materials are used as strong bases in polymers to form carbon-carbon bonds. ${ }^{17}$

\subsection{Lithium production from nature resources}

Even though lithium is used widely, its reserves and production are not evenly distributed across the world. South American nations, such as Chile, Bolivia, and Argentina, own more than $70 \%$ of the global lithium deposits ${ }^{18}$ (Fig. 1b). Australia produces the most lithium (43.5\% of global production), followed by Chile $(32.8 \%){ }^{19}$ Argentina and China export a significant quantity of lithium $^{19}$ (Fig. 1b).

Lithium is extracted from two natural sources: ores and salt lakes. Lithium can be extracted from spodumene, petalite, and eucryptite, and the composition of the lithium in these ores ranges from $2 \%$ to $5.5 \%{ }^{20}$ (Table 1 ). The minerals are crushed, separated by gravity flotation, concentrated, and heat-processed for water leaching, acid treatment, and pressure leaching to produce the lithium solution. $\mathrm{Na}_{2} \mathrm{CO}_{3}$ was added to the lithium solution to extract lithium sediments. ${ }^{18,21,22}$

The second method for extracting lithium is from a salt lake or brine. Lithium brines exist in Argentina, Bolivia, Chile, China, and the USA. ${ }^{21}$ The lithium grade and magnesium/ lithium ratio of the brine are important factors that affect the production cost and time..$^{23-28}$ Table 2 lists the lithium content and $\mathrm{Mg} / \mathrm{Li}$ ratio of the brines currently used in production. ${ }^{21}$ Brine contains 0.02 to $5 \% \mathrm{Li}^{+}$, along with other ions such as $\mathrm{Na}^{+}, \mathrm{K}^{+}, \mathrm{Cl}^{-}$, and $\mathrm{SO}_{4}{ }^{2-} \cdot{ }^{27}$ Lithium is extracted from brine using the precipitation method. Water is evaporated from the brine in

Table 1 Various lithium ores and their lithium content

\begin{tabular}{lll}
\hline Ore & Chemical formula & Li contained $(w \mathrm{t} \%)$ \\
\hline Spodumene & $\mathrm{LiAlSi}_{2} \mathrm{O}_{6}$ & 3.73 \\
Petalite & $\mathrm{LiAlSi}_{4} \mathrm{O}_{10}$ & 2.09 \\
Amblygonite & $(\mathrm{Li}, \mathrm{Na}) \mathrm{AlPO}_{4}(\mathrm{~F}, \mathrm{OH})$ & 3.44 \\
Lepidolite & $\mathrm{K}(\mathrm{Li}, \mathrm{Al})_{3}(\mathrm{Si}, \mathrm{Al})_{4} \mathrm{O}_{10}(\mathrm{~F}, \mathrm{OH})_{2}$ & 3.58 \\
Eucryptite & $\mathrm{LiAlSiO}_{4}$ & 5.51
\end{tabular}

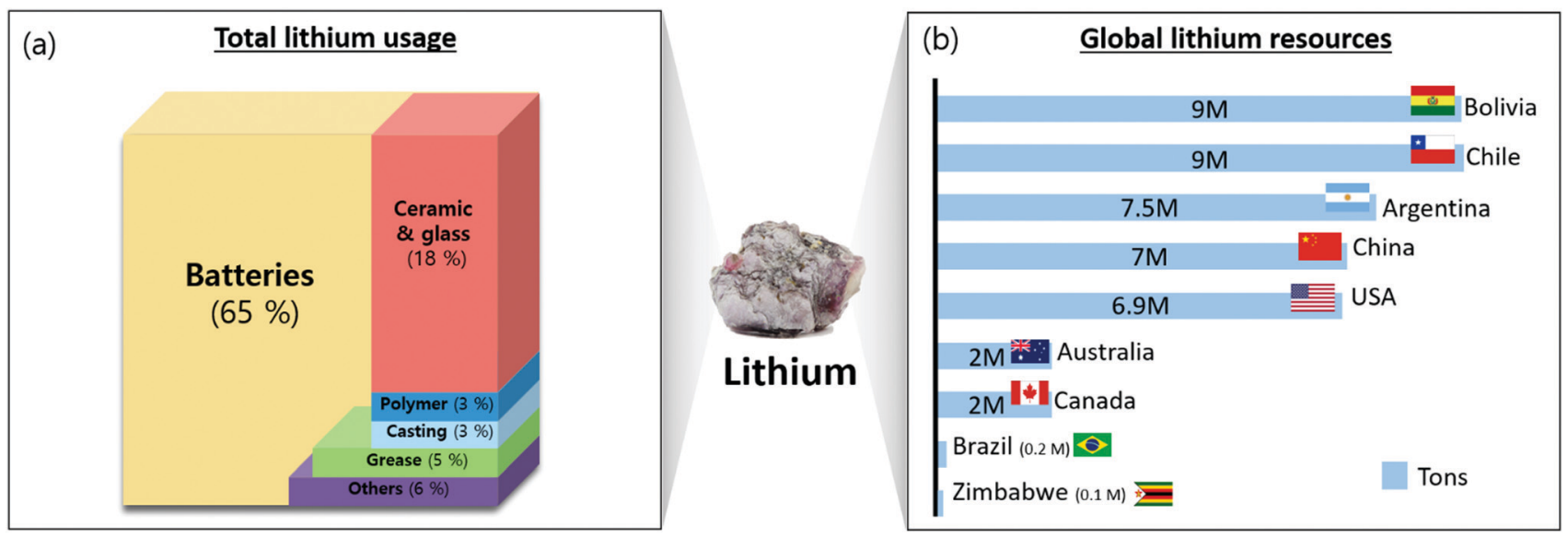

Fig. 1 (a) Distribution of total lithium usage in 2019; (b) distribution of global lithium resources. 
Table 2 Properties of lithium salt lakes

\begin{tabular}{llll}
\hline Salt lake & Country & Li contained (\%/ton) & $\mathrm{Mg} / \mathrm{Li}$ \\
\hline Atacama & Chile & 0.15 & 6.4 \\
Hombre muerto & Argentina & $0.062-5$ & 1.37 \\
Rincon & Argentina & 0.033 & 8.61 \\
Uyuni & Bolivia & 0.035 & $18.6-21.5$ \\
Silver peak & USA & 0.023 & 1.43 \\
Zhabuye lake & China & 0.12 & Low \\
DXC salt lake & China & 0.04 & 0.22 \\
\end{tabular}

a solar pond, followed by the precipitation of $\mathrm{NaCl}$ and $\mathrm{KCl}$, and the concentration of lithium in the solution. Next, $\mathrm{Ca}(\mathrm{OH})_{2}$ is added to the concentrated lithium brine to remove $\mathrm{Mg}$ and sulfate via precipitation. The remaining $\mathrm{Ca}$ and $\mathrm{Na}_{2} \mathrm{CO}_{3}$ in the concentrate are removed via precipitation using $\mathrm{CaCO}_{3}$. This fluid then undergoes filtration and washing and is heated to $80-90{ }^{\circ} \mathrm{C}$ to react with $\mathrm{Na}_{2} \mathrm{CO}_{3}$ and form $\mathrm{Li}_{2} \mathrm{CO}_{3}{ }^{27}$ (Fig. 2) While solar evaporation followed by precipitation is a popular method, the procedure is time-consuming, lasting from 18 to 24 months. ${ }^{28}$ For brines with a high $\mathrm{Mg} / \mathrm{Li}$ ratio, $\mathrm{Al}$ is used to precipitate lithium-aluminate. This method exhibits superior lithium separation and precipitation rates. ${ }^{29}$ This method involves the addition of $\mathrm{AlCl}_{3}, \mathrm{H}_{2} \mathrm{O}$, $\mathrm{NaOH}$, and amorphous $\mathrm{Al}(\mathrm{OH})_{3}$, followed by adjusting the temperature and pH to extract lithium as $\mathrm{LiAlO}_{2}$ (eqn (1)).

$\mathrm{LiCl}+2 \mathrm{AlCl}_{3}+6 \mathrm{NaOH} \rightarrow \mathrm{LiCl} \cdot 2 \mathrm{Al}(\mathrm{OH})_{3} \mathrm{H}_{2} \mathrm{O}+6 \mathrm{NaCl}$

While extracting lithium from ores ensures higher lithium concentration, the production cost is higher than that of brine extraction because of the more energy-intensive procedure. Thus, $87 \%$ of lithium is produced by brine extraction. ${ }^{30}$ Lithium also exists in seawater, which is quite abundant, but its concentration is too low $(0.17 \mathrm{ppm})$ to be economical. ${ }^{31,32}$ However, there are ongoing research efforts to reduce the cost of lithium extraction.

\subsection{Demand for lithium recycling}

The price of $\mathrm{Li}_{2} \mathrm{CO}_{3}$, which is the commonly traded form of lithium in the global market, has increased by 2.6 times from 6500 dollar per metric tons in 2015 to 17000 dollar per metric tons in $2018^{33}$ (Fig. S1, ESI $\dagger$ ). There has been a steady increase in the adoption of lithium-battery-powered personal electronics, electronic vehicles (EVs), and ESS owing to the thrust on green energy. These trends have expanded the lithium-ion battery market to $\$ 44$ billion in $2020 .{ }^{34}$ The growth in the ESS and EV battery markets has further accelerated this expansion. To illustrate the potential increase in demand, it must be noted that while smartphones, laptops, and tablets contain approximately $2 \mathrm{~g}, 6 \mathrm{~g}$, and $20 \mathrm{~g}$ of lithium per device, respectively, ${ }^{35}$ an $\mathrm{EV}$ battery requires approximately $20 \mathrm{~kg}$ of lithium, which is 1000 times that of a smartphone, and a 10 MWh ESS requires at least $700 \mathrm{~kg}$ of lithium. ${ }^{35,36}$ As the demand for lithium-ion batteries increases, the increase in lithium prices can weaken the lithium-ion battery market.

Lithium consumption rose from 49100 tons in 2018 to 57700 tons in 2019, registering an increase of $18 \% .{ }^{37}$ Global lithium reserves are estimated to be approximately 17 billion tons. If the $18 \%$ annual increase in consumption continues, global lithium reserves will be exhausted. In 30 years, the demand for lithium will be approximately 63 million tons, which will be 40 million tons more than the remaining reserves (Fig. 3). Although more lithium reserves may eventually be discovered, the increase in demand is predicted to accelerate owing to the expanding market for lithiumion batteries. An increasing number of agencies across the world forecast shortages of lithium and these predictions have gained much research interest in recent years. ${ }^{38,39}$

\section{Waste lithium-ion battery and pre-treatment}

\subsection{Waste lithium-ion batteries}

Research on lithium recycling has focused mainly on discarded lithium-ion batteries. Lithium-ion batteries function by the movement of $\mathrm{Li}^{+}$ions and electrons, and they consist of an anode, cathode, electrolyte, and separator. The cathode, depending on its usage and capacity, consists of lithium-containing compounds such as $\mathrm{LiFePO}_{4}$ and $\mathrm{LiNi}_{0.3} \mathrm{Mn}_{0.3} \mathrm{Co}_{0.3} \mathrm{O}_{2}$. The anode consists of carbon materials like graphite that can accept lithium ions. The cathode and the anode are connected to aluminum or copper foil

\section{Lithium production}
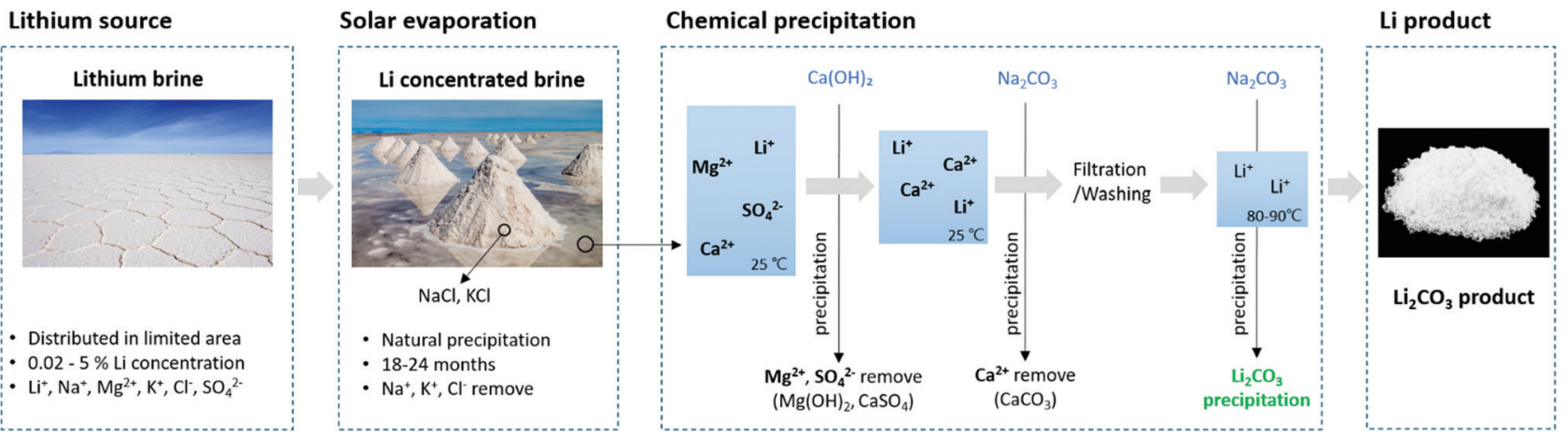

Fig. 2 Process example of Lithium extraction processes from natural lithium brine via chemical precipitation. 


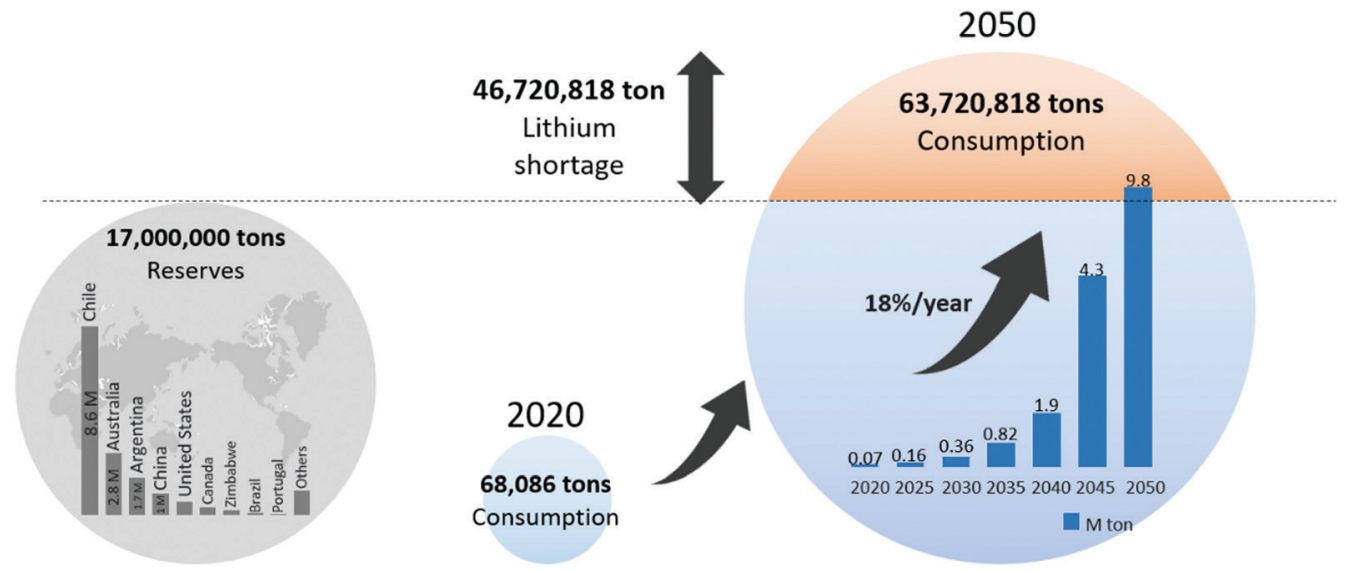

Fig. 3 Global lithium reserves and lithium depletion scenario after 30 years when lithium consumption increasing rate is $18 \%$ per year.

\section{Current state of waste Lithium batteries}

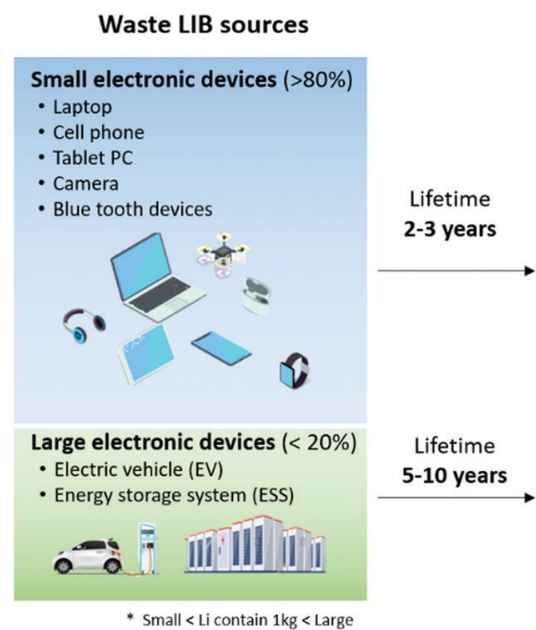

Global Waste LIB amount (estimation)

Waste LIB collection
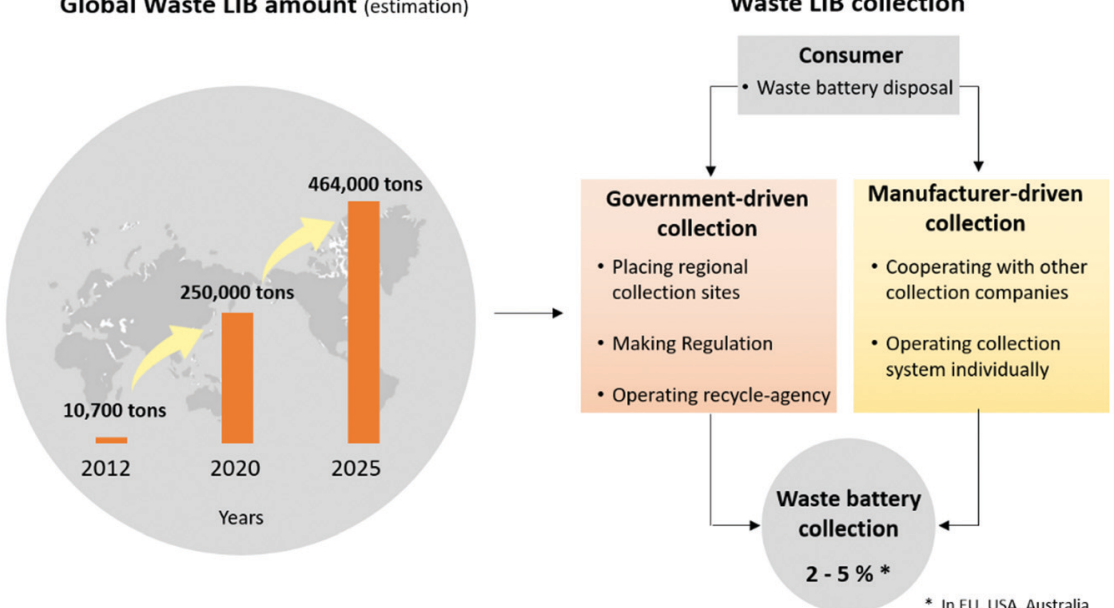

Fig. 4 Sources, quantity and collection of discarded lithium-ion batteries.

with a polymer binder such as polyvinylidene fluoride (PVDF), for electrical conduction and stability. Electrolytes are usually liquids and act to deliver lithium ions between the cathode and anode. These are usually lithium salts $\left(e . g\right.$., $\left.\mathrm{LiPF}_{6}\right)$ dissolved in organic solvents such as ethylene carbonate (EC) or dimethyl carbonate (DMC). Polymers such as polypropylene (PP) or polyethylene (PE) are used as separators to prevent physical contact and direct electron transfer between the cathode and the anode.

A lithium-ion battery can last up to three years in a small electronic device, and from five to ten years in a larger device; this is shorter than the lifespan of other batteries, considering that $\mathrm{Ni}-\mathrm{Cd}$ batteries last from fifteen to twenty years, and leadacid batteries last from five to ten years. ${ }^{40-44}$ Currently, $80 \%$ of lithium-ion batteries are used for small electronics, with EV and ESS applications accounting for less than $20 \% .{ }^{45}$ Lithiumion battery disposal was estimated to be 10700 tons in $2012 .^{46}$ This value has increased progressively each year, with an estimate of up to 250000 tons in $2020 .{ }^{45}$ With the large-scale adoption of EVs and ESSs, the number of lithium-ion batteries in service is expected to increase. Discarded lithium-ion batteries are collected by government authorities or companies authorized by the manufacturer. Consumers normally dispose of lithium-ion batteries in a government-designated area or these are directly collected by the relevant agency. However, only $2-5 \%$ of lithiumion batteries are collected in Australia, the EU, and the $\mathrm{US}^{47}$ (Fig. 4). The reason for the low collection rate is the lack of consumer awareness, as well as the tendency to resell electronics rather than recycle them. Although it may vary by country, there is a lack of legal and physical infrastructure for widespread collection and efficient, safe, and economical transportation of the disposed lithium-ion batteries. Major improvements are required to significantly increase the collection rate.

Recycling of lithium-ion batteries has been steadily researched since the 1990s and has recently gained traction. However, most research focuses not on lithium but on more expensive materials, such as cobalt. Therefore, little focus has been placed on extracting lithium from disposed batteries. Cobalt is the most expensive material in a lithium-ion battery; thus, there has been considerable 


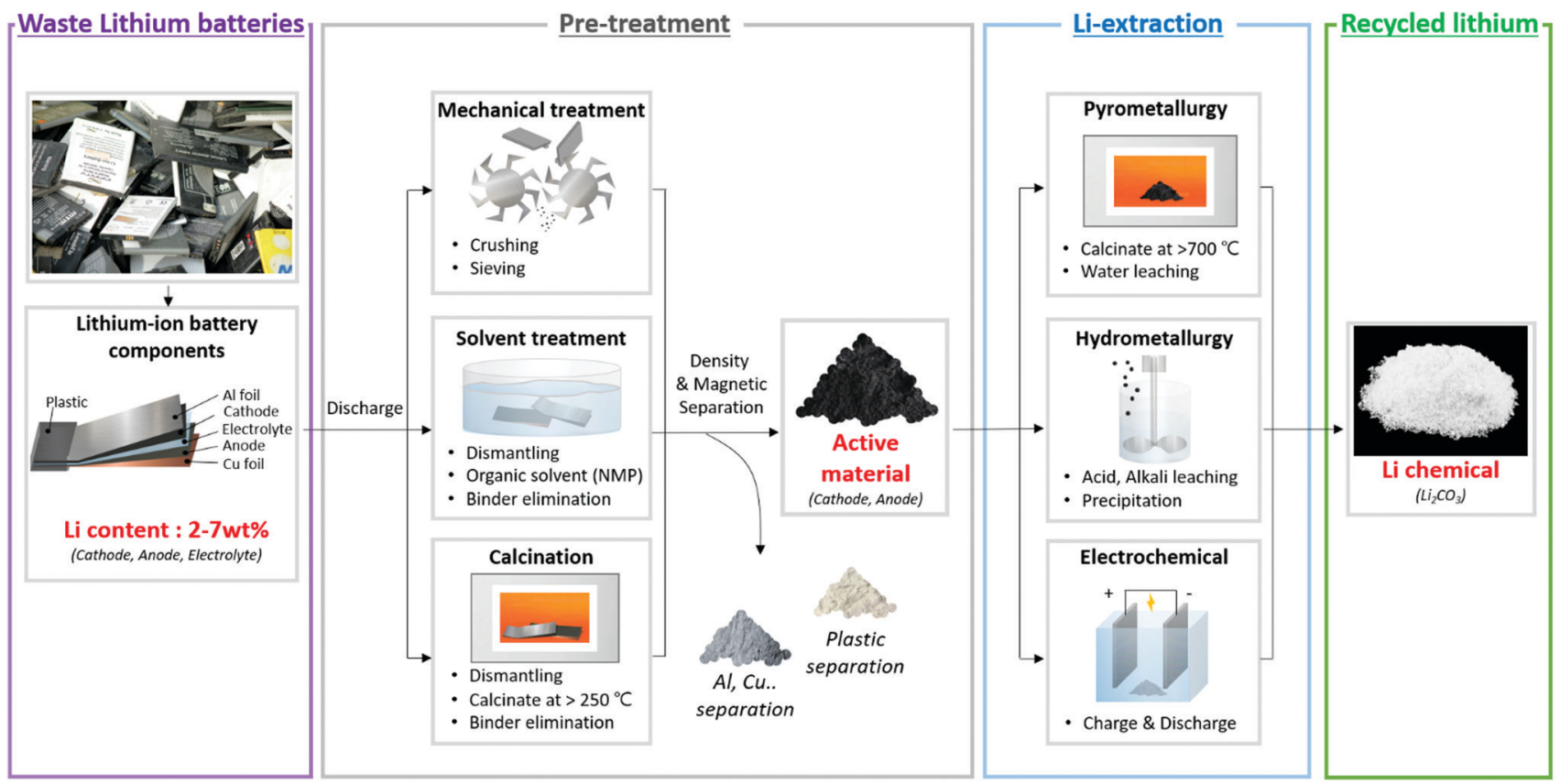

Fig. 5 Schematic diagram of the overall lithium recycling stages and methods from discarded lithium-ion batteries.

research interest in reducing the cobalt content or replacing it by using $\mathrm{LiFePO}_{4}$ or $\mathrm{LiNi}_{0.3} \mathrm{Mn}_{0.3} \mathrm{Co}_{0.3} \mathrm{O}_{2}{ }^{48}$ However, lithium is an irreplaceable key component in lithium-ion batteries, and it is used in the cathode, electrolyte and anode. Therefore a comprehensive review of the recycling of lithium from lithium-ion battery recycling is needed.

Lithium can be extracted from a lithium-ion battery via two major processes. Owing to the difficulty of separating lithium from the packed battery, the disposed battery is subjected to a pre-treatment process to separate the lithium-containing active material(cathode, anode) from the peripheral parts(plastic, polymer). Next, lithium is chemically separated from the active materials using pyrometallurgy, hydrometallurgy and electrochemical extraction methods (Fig. 5). The two processes, pretreatment and lithium extraction, are explained.

\subsection{Pre-treatment methods for waste lithium-ion battery}

Quantifying the remaining power of a discarded lithium-ion battery is difficult. Even after depleting charge of the battery, the battery might still have some power remained. In addition, because lithium-ion batteries contain various materials, it is not efficient to treat the batteries directly. Therefore, a pretreatment process is essential. Waste lithium-ion batteries can be pre-treated and separated safely only when they are fully discharged. If not, the battery can explode or emit toxic gases due to local short-circuiting. Hauck and Kurrat reviewed various methods for discharging batteries using electronic techniques and conductive liquids. ${ }^{49}$ The most used method is to submerge the battery in a conductive solution, such as a $\mathrm{NaCl}$ solution. Although $\mathrm{NaCl}$ is the most popular conductive solution, there is ongoing research on the discharge rate and corrosion rate of other conductive liquids. ${ }^{50,51}$ Methods to separate the active material from the disposed battery can be broadly categorized as mechanical separation, solution treatment separation, and calcination treatment separation (Fig. 6).

3.2.1 Mechanical pre-treatment. Mechanical pre-treatment is a treatment method that involves physically grinding the discharged lithium-ion batteries. ${ }^{54-57}$ Different compartments of the battery have different mechanical properties, and so, a grinder that can uniformly grind all the compartments is

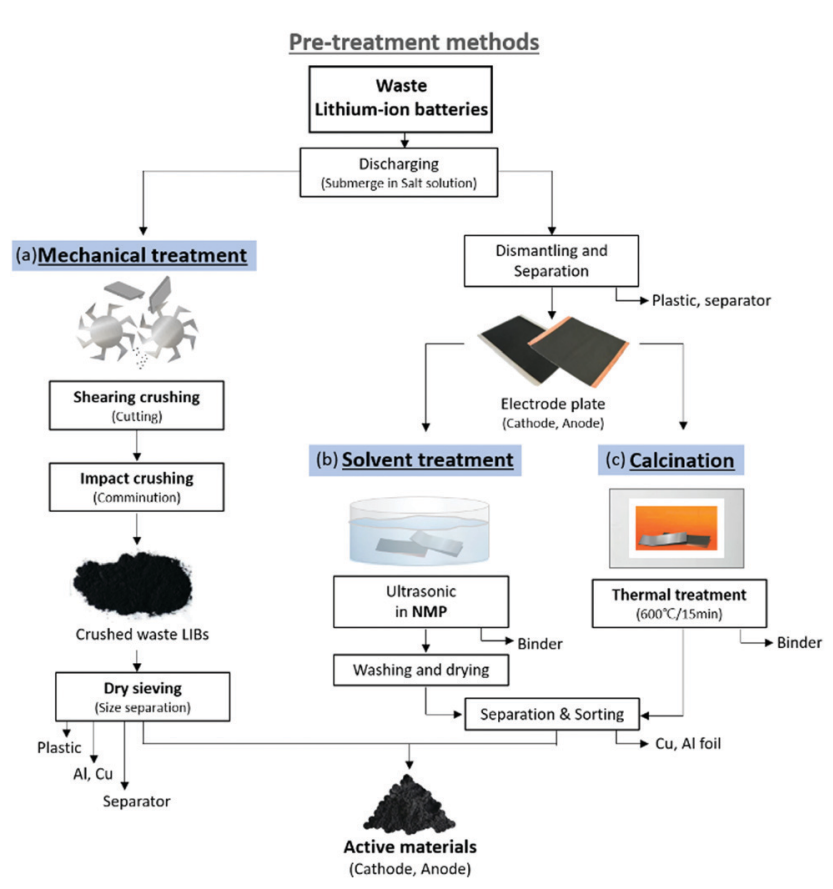

Fig. 6 Example of pre-treatment technology and processes of waste LIBs; (a) mechanical (b) solvent treat and (c) calcination. 
needed. Generally, a grinding chamber is created by blocking off air. Various tools, such as hammer mills, granulator machines and blade crushers are used. After grinding, the active material (cathode, anode) and miscellaneous (Al, $\mathrm{Cu}$ ) are separated by utilizing the difference in density and magnetic properties. Zhang et al. created battery pieces by shear crushing a waste battery discharged via $\mathrm{NaCl}$ solution immersion. ${ }^{52}$ They used impact crushing equipment fitted with blade crushers and ground the battery for $20 \mathrm{~s}$ at $3000 \mathrm{rpm}$. The crushed pieces were categorized into four size groups via dry sieving. The larger pieces of plastic, $\mathrm{Al}, \mathrm{Cu}$ and polymers were separated from the cathode and anode materials of $0.075 \mathrm{~mm}$. After removing the hydrocarbon material on the surface, $\mathrm{LiCoO}_{2}$ and graphite were separated via flotation (Fig. 6a). Mechanical pre-treatment is the most common method of lithium-ion battery separation owing to its simplicity and scalability. However, setting up a stable separation setup is essential, and this method can result in the production of noise, dust, and harmful gases. In addition, it is difficult to ensure the perfect separation of all materials using this method.

3.2.2 Solvent pre-treatment. Solvent pre-treatment utilizes solutions and solvents to separate the active materials from the $\mathrm{Al}$ and $\mathrm{Cu}$ foils in the lithium-ion battery. ${ }^{58-61}$ This method removes the additive binder material that strengthens the foil contact with the active materials, thereby separating the active materials. The cathode and anode were combined with a binder on $\mathrm{Al}$ and $\mathrm{Cu}$ foil. By stripping off the binder, the active material can be separated from the metal foil. A well-known method is to insert the electrode plate into an organic solvent ( $N$-methyl-2-pyrrolidine (NMP)) at $100{ }^{\circ} \mathrm{C}$ to remove the binder and separate the $\mathrm{Al}$ and $\mathrm{Cu}$ foils. $\mathrm{He}$ et al. discharged the lithium-ion battery by submerging it in a $\mathrm{NaCl}$ solution and separated the battery by hand using sharp nose pliers. ${ }^{60}$ After separating the plastic, metal case, electrode plate, and separator, the cathode was cut into small pieces. The cathode pieces were placed in NMP at $80{ }^{\circ} \mathrm{C}$ for $2 \mathrm{~h}$, thereby dissolving the binder and separating the $\mathrm{Al}$ foil and cathode material (Fig. 6b). Most batteries use a PVDF binder to attach the active materials, but some use PTFE binders, which require the selection of an appropriate organic solvent. Furthermore, this method requires the use of organic solvents around $100{ }^{\circ} \mathrm{C}$, which increases the cost and creates harmful waste products.

3.2.3 Calcination pre-treatment. Calcination per-treatment occurs in the temperature range of $150-500{ }^{\circ} \mathrm{C}$ to remove carbon and organic material from the discarded lithium-ion battery. ${ }^{62-65}$ In addition, by calcinating at $250{ }^{\circ} \mathrm{C}$ to $350{ }^{\circ} \mathrm{C}$, the PVDF binder (which connects the active materials and metal foil) can be removed, thereby reducing the adherence of the active materials on the $\mathrm{Al}$ and $\mathrm{Cu}$ foils. Yang et al. cut the cathode parts into small pieces and placed them in a tube furnace in a nitrogen atmosphere at 550-650 ${ }^{\circ} \mathrm{C}^{65}$ Then, the cathode material and the current collector (Al foil) were easily separated using gravity separation (Fig. 6c). However, calcination treatment requires expensive calcination equipment, is energy-intensive, and can emit toxic gases.

Various methods can be used to pre-treat discarded lithiumion batteries. Each method has its advantages and drawbacks, and a more scalable method needs to be developed for use on a commercial scale. Table 3 lists the results and conditions of the different pre-treatment methods.

\section{Lithium extraction technologies from pre-treated waste lithium-ion battery}

Various methods are used to extract lithium from the active material obtained from the pre-treatment. Most methods focus

Table 3 Summary of condition and residue parameters of pre-treatment processes of waste LIBs investigated in the literature

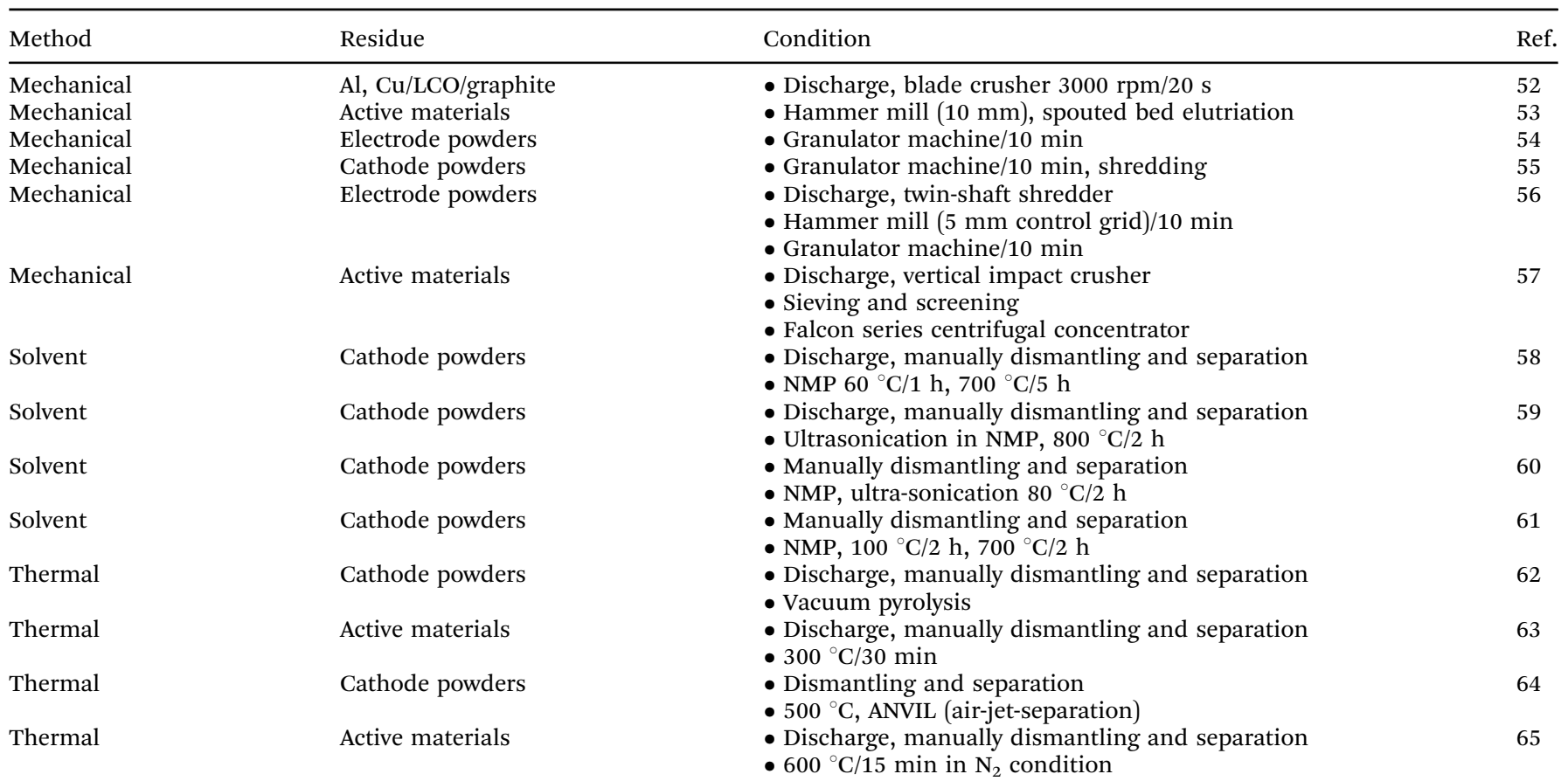


on the extraction of $\mathrm{Co}, \mathrm{Ni}$, or $\mathrm{Mn}$; however, this study focused on the extraction of lithium. In addition, this review excludes methods that have leaching solutions as the end product and focuses on technologies that produce usable lithium compounds such as $\mathrm{Li}_{2} \mathrm{CO}_{3}$ and $\mathrm{Li}_{3} \mathrm{PO}_{4}$. Fig. 4 shows the three lithium extraction methods: pyrometallurgy, hydrometallurgy, and electrochemical extraction.

\subsection{Pyrometallurgy}

Pyrometallurgy uses high temperatures to remove organic material via evaporation and causes reactions in the cathode and anode to make lithium soluble in water. ${ }^{66-76}$ Lithium was then recycled from the aqueous solution. The pre-treated active materials were powdered and subjected to calcination. At temperatures higher than $700{ }^{\circ} \mathrm{C}$, the lithium metal oxide of the cathode and anode react to form $\mathrm{Li}_{2} \mathrm{CO}_{3}$ and metal oxides. The reactions that occur are shown in eqn (2)-(6).

$$
\begin{gathered}
\mathrm{C}+12 \mathrm{LiMO}_{2} \rightarrow 6 \mathrm{Li}_{2} \mathrm{O}+4 \mathrm{M}_{3} \mathrm{O}_{4}+\mathrm{CO}_{2} \\
\mathrm{C}+4 \mathrm{LiMO}_{2} \rightarrow 2 \mathrm{Li}_{2} \mathrm{O}+4 \mathrm{MO}+\mathrm{CO}_{2} \\
2 \mathrm{M}_{3} \mathrm{O}_{4}+\mathrm{C} \rightarrow 6 \mathrm{MO}+\mathrm{CO}_{2} \\
\mathrm{Li}_{2} \mathrm{O}+\mathrm{CO}_{2} \rightarrow \mathrm{Li}_{2} \mathrm{CO}_{3} \\
2 \mathrm{MO}+\mathrm{C} \rightarrow 2 \mathrm{M}+\mathrm{CO}_{2}
\end{gathered}
$$

The calcinated powder then undergoes water leaching to dissolve the lithium $\left(\mathrm{Li}_{2} \mathrm{CO}_{3}\right)$ in the water. The metal oxide does not dissolve in the water. After water leaching via filtration, the undissolved metal oxide and the aqueous solution were separated to produce a $\mathrm{Li}_{2} \mathrm{CO}_{3}$ solution, followed by water evaporation to finally obtain $\mathrm{Li}_{2} \mathrm{CO}_{3}$ (Fig. 7). This method can process large numbers of disposed lithium-ion batteries, and the process is simple. Li et al. recycled lithium via pyrometallurgy using $\mathrm{LiCoO}_{2}$ and graphite from a pre-treated lithium-ion battery. ${ }^{67}$
The separated active materials were calcined in nitrogen at $1000{ }^{\circ} \mathrm{C}$ for $30 \mathrm{~min}$ to obtain $\mathrm{Co}, \mathrm{Li}_{2} \mathrm{CO}_{3}$, and graphite compounds. This compound was submerged in water to separate lithium using wet magnetic separation. Pindar et al. separated lithium-ion batteries and calcinated them at $800{ }^{\circ} \mathrm{C}$ for $45 \mathrm{~min}$ to create a lithium-containing powder, which was dissolved in a mass of water 50 times more than the powder mass. ${ }^{72}$ This resulted in $\mathrm{Li}_{2} \mathrm{CO}_{3}$ with $\mathrm{LiF}$ mixed at a $90 \%$ lithium retrieval rate. Xiao et al. used pyrometallurgy to separate lithium from $\mathrm{LiMn}_{2} \mathrm{O}_{4}, \mathrm{LiCoO}_{2}$, and $\mathrm{LiMn}_{x} \mathrm{Co}_{y} \mathrm{Ni}_{z} \mathrm{O}_{2}$ mixed with graphite. The cathode material was separated from the battery and calcinated at $700{ }^{\circ} \mathrm{C}$ in vacuum for $30 \mathrm{~min}$. The calcinated powder was a metal oxide, $\mathrm{Li}_{2} \mathrm{CO}_{3}$, which was then reacted with water $\left(25 \mathrm{~g} \mathrm{~L}^{-1}\right)$ for separation. ${ }^{68}$

Some pyrometallurgy uses additional acids for the roasting to higher the lithium extraction efficiency. Liu et al. used nitric acid to nitrate the lithium ion-battery scraps and roasted them at $250{ }^{\circ} \mathrm{C}$ for $60 \mathrm{~min}$. After roasting, by leaching with water, lithium solution was produced and with carbonation, $\mathrm{Li}_{2} \mathrm{CO}_{3}$ was produced with low-temperature roasting. ${ }^{73} \mathrm{Li}$ et al. used sulfation roasting to recycle $\mathrm{Li}_{2} \mathrm{SO}_{4}$ from NCM523 material by using $\mathrm{H}_{2} \mathrm{SO}_{4}$ with the process of roasting and water leaching. ${ }^{76}$

Chlorination roasting is also used in pyrometallurgy, which uses sintered lithium slag $\left(x \mathrm{Li}_{2} \mathrm{O} \cdot y \mathrm{CaO} \cdot z \mathrm{Al}_{2} \mathrm{O}_{3} \cdot n \mathrm{SiO}_{2}\right)$ with chlorine donor to form $\mathrm{LiCl}$ after the roasting. Chang et al. used $\mathrm{CaCl}_{2}$ and roasted it at $1000{ }^{\circ} \mathrm{C}$ for $90 \mathrm{~min}$ with $\mathrm{LiAl}\left(\mathrm{SiO}_{3}\right)_{2}$ to transform it into $\mathrm{LiCl}^{71}$ (eqn (7)).

$$
\mathrm{CaCl}_{2}+\mathrm{Li}_{2} \mathrm{O} \rightarrow \mathrm{CaO}+2 \mathrm{LiCl}
$$

The biggest drawback of the pyrometallurgy method for lithium recycling is that additional steps are required after calcination. This additional process usually involves dissolving the product in water or solvent and separating it.

However, the low solubility of $\mathrm{Li}_{2} \mathrm{CO}_{3}\left(13 \mathrm{~g} \mathrm{~L}^{-1}\right)$ requires a large amount of solvent. In addition, the pyrometallurgy

\section{Pyrometallurgy}

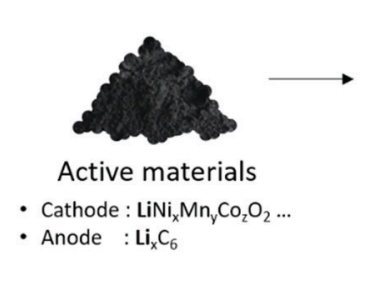

- Cathode : $\mathrm{LiNi}_{\mathrm{x}} \mathrm{Mn}_{\mathrm{y}} \mathrm{CO}_{2} \mathrm{O}_{2}$

Anode : $\mathrm{Li}_{\mathrm{x}} \mathrm{C}_{6}$

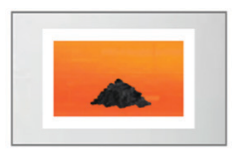

Calcination

- Calcination $>700^{\circ} \mathrm{C}$

- $\mathrm{LiMO}_{2}$ decomposition

- $\mathrm{Li}_{2} \mathrm{CO}_{3}$ formation

${ }^{*} \mathrm{M}=\mathrm{Co}, \mathrm{Mn}, \mathrm{Ni}$

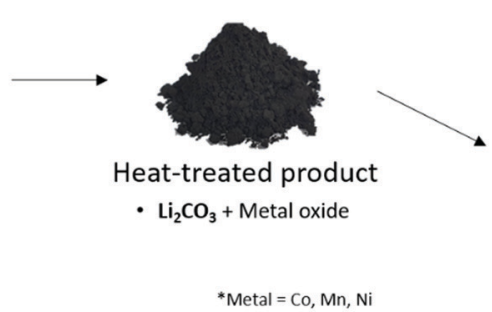

*Metal $=\mathrm{Co}, \mathrm{Mn}, \mathrm{Ni}$

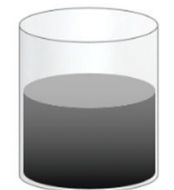

Water leaching

- $\mathrm{Li}_{2} \mathrm{CO}_{3} \rightarrow$ Soluble

- Metal oxide $\rightarrow$ Insoluble

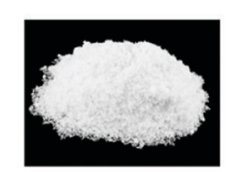

Lithium chemical $\left(\mathrm{Li}_{2} \mathrm{CO}_{3}\right)$

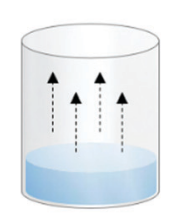

Water evaporation

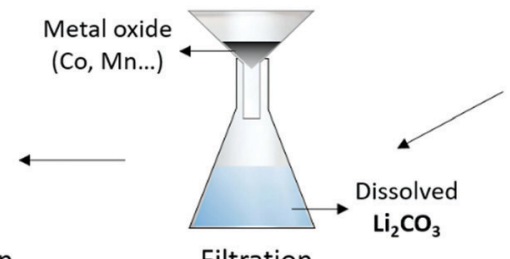

Filtration

- Metal oxide $\rightarrow$ Filtered

- $\mathrm{Li}_{2} \mathrm{CO}_{3}$ dissolved in water

Fig. 7 Overall schematic of lithium recycling from pre-treated waste LIB components by pyrometallurgy process. 
Table 4 Summary of condition and residue parameters of pyrometallurgy processes of waste LIBs investigated in the literature

\begin{tabular}{|c|c|c|c|c|c|}
\hline Spent materials & Residue & Efficiency & Purity & Condition & Ref. \\
\hline $\mathrm{LiCoO}_{2}+\mathrm{C}$ & $\mathrm{Co}+\mathrm{Li}_{2} \mathrm{CO}_{3}+\mathrm{C}$ & $98.93 \%$ & - & - $1000^{\circ} \mathrm{C} / 30 \mathrm{~min}$ in $\mathrm{O}_{2}$ free & 67 \\
\hline $\mathrm{C}+\mathrm{LiMn}_{2} \mathrm{O}_{4}, \mathrm{LiCoO}_{2}, \mathrm{LiMn}_{x} \mathrm{Co}_{y} \mathrm{Ni}_{z} \mathrm{O}_{2}$ & $\mathrm{Li}_{2} \mathrm{CO}_{3}+$ metal oxide & $81.90 \%$ & $99.7 \%$ & - $700{ }^{\circ} \mathrm{C} / 30 \mathrm{~min}$ & 68 \\
\hline Cathode materials & $\mathrm{Li}_{2} \mathrm{CO}_{3}$ & $84.7 \%$ & - & $\begin{array}{l}\text { - } 650{ }^{\circ} \mathrm{C} / 3 \mathrm{~h} \\
\text { - Water leaching }\left[100{ }^{\circ} \mathrm{C} / 0.5 \mathrm{~h}\right]\end{array}$ & 70 \\
\hline LIB lithium slag & $\mathrm{LiCl}$ & Evaporate $97.45 \%$ & - & $\begin{array}{l}\bullet 1200{ }^{\circ} \mathrm{C} / 1 \mathrm{~h} \\
\cdot 1000{ }^{\circ} \mathrm{C} / 90 \mathrm{~min} \text { with } \mathrm{CaCl}_{2}\end{array}$ & 71 \\
\hline LIB scraps & $\mathrm{Li}_{2} \mathrm{CO}_{3}$ & $90 \%$ & $99.95 \%$ & $\begin{array}{l}\text { - } 70{ }^{\circ} \mathrm{C} / 5 \mathrm{~h} \mathrm{HNO}_{3} \\
\text { - Roasting } 100-300{ }^{\circ} \mathrm{C}\end{array}$ & 73 \\
\hline $\mathrm{LiCoO}_{2}$ & $\mathrm{Li}_{2} \mathrm{CO}_{3}$ solution & $36 \%$ & - & - $700{ }^{\circ} \mathrm{C}$ with carbon & 74 \\
\hline Electrode materials & $\mathrm{Li}_{2} \mathrm{CO}_{3}$ & $80 \%$ & $98 \%$ & - Carbothermal $850{ }^{\circ} \mathrm{C} / 45 \mathrm{~min}$ & 75 \\
\hline
\end{tabular}

method requires complicated calcination equipment and can cause the emission of harmful gases. Table 4 summarizes the details of the pyrometallurgy research.

\subsection{Hydrometallurgy}

Hydrometallurgy is the most used method for lithium extraction. It ionizes the lithium in the pre-treated active materials with acids and bases, followed by leaching to obtain $\mathrm{Li}^{+}$ solutions from which lithium can be extracted. Inorganic acids such as sulfuric acid, hydrochloric acid, and nitric acid were used. Heat or redox reactions using $\mathrm{H}_{2} \mathrm{SO}_{3}, \mathrm{NH}_{2} \mathrm{OH}$, and $\mathrm{H}_{2} \mathrm{O}_{2}$ were applied to increase the leaching efficiency. Among the redox agents, $\mathrm{H}_{2} \mathrm{O}_{2}$ is the most common reductant because of its low cost and non-toxicity. $\mathrm{H}_{2} \mathrm{O}_{2}$ can increase the leaching reaction rate owing to its strong reducibility. However, using an acid with a low $\mathrm{pH}$ can result in the emission of harmful gases such as $\mathrm{Cl}_{2}$ and NOx, which affects the environment adversely. Thus, the use of weak acids, such as oxalic acid or citric acid, is being examined. Lithium compounds can be created using acids or bases for leaching, followed by precipitation, solvent extraction, or selective adsorption ${ }^{77-103}$ (Fig. 8).

4.2.1 Precipitation. Precipitation is the most used method for separating lithium from leached solutions. This method uses the difference in the solubility of metal compounds, which is dependent on the specific $\mathrm{pH}$ and temperature. ${ }^{77-97}$ Materials with low solubility, such as transition metal hydroxides or oxalates, are precipitated. Therefore, precipitants such as $\mathrm{NaOH}$, $\mathrm{Na}_{3} \mathrm{PO}_{4}$, and $\mathrm{Na}_{2} \mathrm{CO}_{3}$ are mainly used to precipitate other dissolved metals, followed by lithium extraction in the form of $\mathrm{Li}_{2} \mathrm{CO}_{3}$ or $\mathrm{Li}_{3} \mathrm{PO}_{4}$ by reacting $\mathrm{Li}^{+}$and precipitants. For example, $\mathrm{Li}_{2} \mathrm{CO}_{3}$ has a higher tendency to form low-solubility $\mathrm{Li}_{2} \mathrm{CO}_{3}$ under high $\mathrm{pH}$ conditions because of the formation of $\mathrm{CO}_{3}{ }^{2-}$ ions. Also, the solubility decreases at higher temperatures $\left(12.9 \mathrm{~g} \mathrm{~L}^{-1}\right.$ at $25{ }^{\circ} \mathrm{C}, 10.8 \mathrm{~g} \mathrm{~L}^{-1}$ at $40{ }^{\circ} \mathrm{C}$ ), which makes precipitation easier. Compared to other compounds ( $\mathrm{LiOH}-129 \mathrm{~g} \mathrm{~L}^{-1}, \mathrm{LiCl}-815 \mathrm{~g} \mathrm{~L}^{-1}$ at $\left.25{ }^{\circ} \mathrm{C}\right) \mathrm{Li}_{2} \mathrm{CO}_{3}$ has a substantially lower solubility, which makes

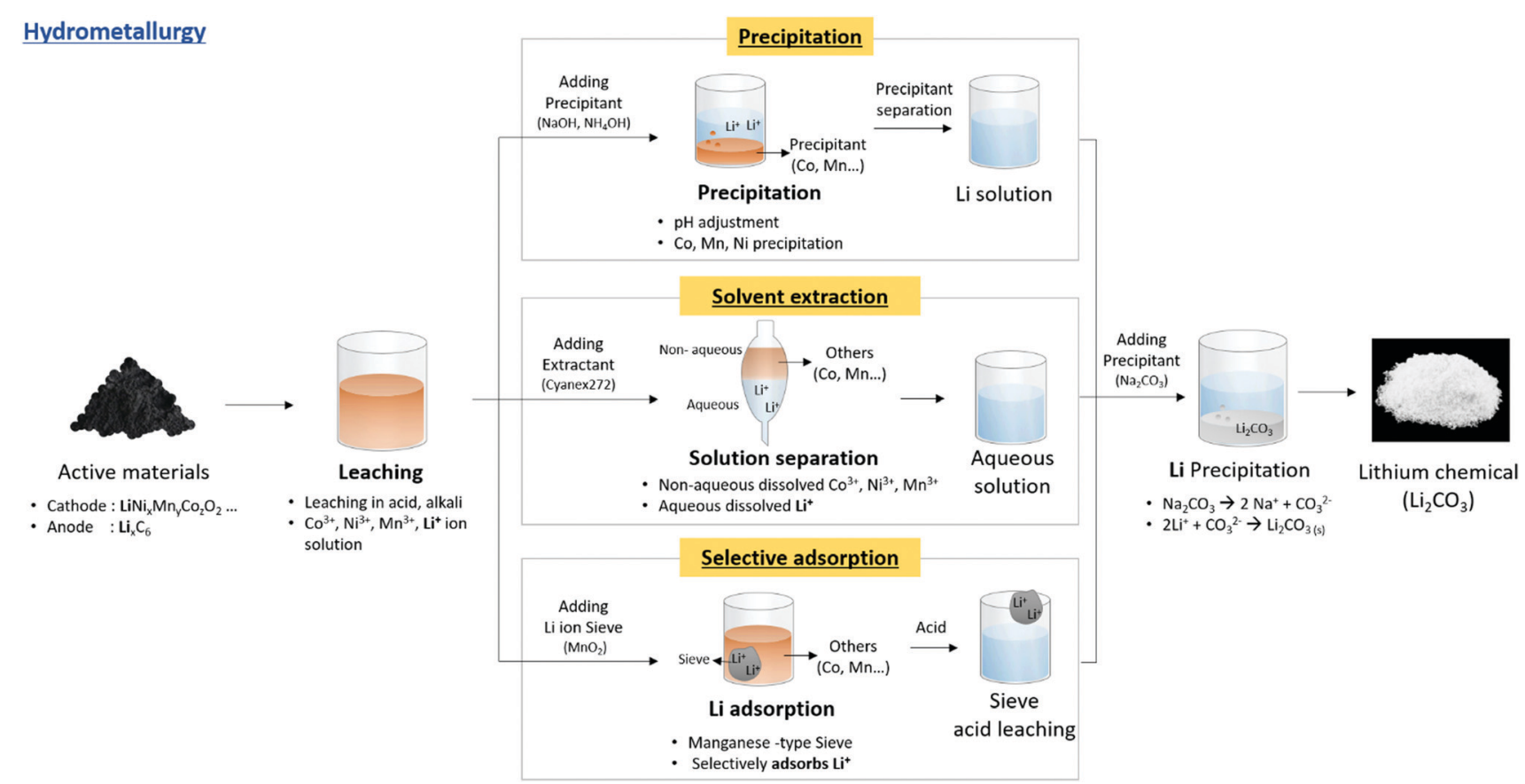

Fig. 8 Overall schematic of lithium recycling from pre-treated waste LIB components by hydrometallurgy process. 
it easier to precipitate. This method is the safest, most economical, and most efficient (retrieval efficiency) among hydrometallurgy methods. Gao et al. precipitated $\mathrm{Li}_{2} \mathrm{CO}_{3}$ from separated $\mathrm{LiNi}_{0.3} \mathrm{Mn}_{0.3} \mathrm{Co}_{0.3} \mathrm{O}_{2}$ electrode material. ${ }^{84} \mathrm{LiNi}_{0.3} \mathrm{Mn}_{0.3} \mathrm{Co}_{0.3} \mathrm{O}_{2}$ was leached using $2 \mathrm{M}$ formic acid at $70{ }^{\circ} \mathrm{C}$ and $\mathrm{H}_{2} \mathrm{O}_{2}$ as reductant, followed by an increase in $\mathrm{pH}$ when using $\mathrm{NaOH}$ and $\mathrm{NH}_{4} \mathrm{OH}$ solutions. The increase in $\mathrm{pH}$ precipitates $\mathrm{Co}, \mathrm{Mn}$, and $\mathrm{Ni}$ as hydroxides, which are separated. A saturated $\mathrm{Na}_{2} \mathrm{CO}_{3}$ solution was added to the solution to create $\mathrm{Li}_{2} \mathrm{CO}_{3}$. This method reportedly retrieved $98.22 \%$ of lithium. Yang et al. used precipitation to separate lithium from $\mathrm{LiFePO}_{4}$, a lithium-ion battery cathode. ${ }^{85} \mathrm{LiFePO}_{4}$ cathodes are difficult to leach and so, the crystal structure needs to be destroyed via calcination or chemical treatment before leaching. To destroy the crystal structure, $\mathrm{LiFePO}_{4}$ was ball-milled with DEDTA-2Na, and the leaching rate was increased by mechanochemical activation. Leaching was performed for 20 min using $0.6 \mathrm{M} \mathrm{H}_{3} \mathrm{PO}_{4}\left(50 \mathrm{~g} \mathrm{~L}^{-1}\right)$, followed by stirring for $9 \mathrm{~h}$ at $90{ }^{\circ} \mathrm{C}$ to separate $\mathrm{FePO}_{4}$ and adding $5 \mathrm{M}$ of $\mathrm{NaOH}$ to precipitate lithium as $\mathrm{Li}_{3} \mathrm{PO}_{4}$. Natarajan et al. obtained $\mathrm{Li}_{2} \mathrm{CO}_{3}$ from a cathode containing Co and $\mathrm{Mn}$. Using $3 \mathrm{M}$ acetic acid and $\mathrm{H}_{2} \mathrm{O}_{2}$, the anode material was leached, followed by the addition of $\left(\mathrm{NH}_{4}\right)_{2} \mathrm{~S}$ to precipitate Co as $\mathrm{CoS}$, and the addition of $\mathrm{Na}_{2} \mathrm{CO}_{3}$ to precipitate $\mathrm{Mn}$ as $\mathrm{MnCO}_{3} \cdot{ }^{86}$ After the removal of $\mathrm{Co}$ and $\mathrm{Mn}, \mathrm{Na}_{2} \mathrm{CO}_{3}$ was added to the solution to precipitate $\mathrm{Li}_{2} \mathrm{CO}_{3}$. Recycling lithium from the anode material (graphite) is investigated by Yang et al. They collected graphite by two stage calcination process. After, with $1.5 \mathrm{M}$ of $\mathrm{HCl}$, lithium was almost $100 \%$ leached into a liquor. By adjusting the $\mathrm{pH}$ and adding the sodium carbonate to the solution, $\mathrm{Li}_{2} \mathrm{CO}_{3}$ was precipitated.

These precipitation methods are most researched, but fine control of the operating conditions $(\mathrm{pH}, \mathrm{Li}$ concentration, and temperature) is needed to produce the required property profile.

4.2.2 Solvent extraction. Solvent extraction uses a two-phase system to separate lithium from the leached cathode material. ${ }^{98-102}$ It uses relative solubility to separate ions from polar and nonpolar liquids. Nonpolar extractants are mainly used to separate valuable metals (Co, Ni, Mn), and lithium is separated from the stratified solution. Cyanex272, PC-88a, and D2EHPA were used to separate $\mathrm{Co}, \mathrm{Ni}$, and Mn. Zhang et al. used solvent extraction to separate lithium from $\mathrm{LiCoO}_{2} \cdot{ }^{98}$ The cathode material was leached using $\mathrm{HCl}$, and PC-88A was used to separate the Co and $\mathrm{Li}$ ions. An increase in $\mathrm{pH}$ caused $\mathrm{PC}-88 \mathrm{~A}$ to extract cobalt more efficiently. Using this property, at pH 6.7, cobalt was separated using an organic solvent, and lithium was separated as an aqueous solution. After cobalt extraction, the separated raffinate (lithium aqueous solution) was added to $\mathrm{Na}_{2} \mathrm{CO}_{3}$ to precipitate $\mathrm{Li}_{2} \mathrm{CO}_{3}$. Chen et al. extracted lithium from $\mathrm{LiNi}_{0.3} \mathrm{Mn}_{0.3} \mathrm{Co}_{0.3} \mathrm{O}_{2}$. ${ }^{100}$ They leached the $\mathrm{LiNi}_{0.3} \mathrm{Mn}_{0.3} \mathrm{Co}_{0.3} \mathrm{O}_{2}$ powder using $2 \mathrm{M} \mathrm{H}_{2} \mathrm{SO}_{4}$ in $70{ }^{\circ} \mathrm{C}$ for $90 \mathrm{~min}$, followed by $0.1 \mathrm{M}$ Na-Cyanex272 at $\mathrm{pH} 6$ to separate cobalt and manganese (as an organic solvent), and lithium and nickel (as an aqueous solution). Cobalt and manganese were separated from the organic solvent using 0.2 M Na-D2EHPA at $\mathrm{pH}$ 2.95. Lithium and nickel are separated from the aqueous solution at $\mathrm{pH} 9$ using dimethylglyoxime (DMG), which has low reactivity with lithium but high reactivity with nickel in $\mathrm{pH}$ 9. The nickel is separated as a solid, leaving a solution with only lithium. $\mathrm{Na}_{2} \mathrm{CO}_{3}$ was added to the solution to obtain $\mathrm{Li}_{2} \mathrm{CO}_{3}$. Recently, a compound called Cyanex936P was developed, which can separate lithium from other alkaline metals. This has the potential to be a great extractant for lithium-ion battery recycling. Solvent extraction is a shorter process than precipitation but requires additional extractant chemicals such as cyanex272 and PC-88A, along with expensive solvents. In addition, detailed control of the conditions, such as $\mathrm{pH}$ and solvent concentration, is needed because the extraction efficiency is greatly affected.

4.2.3 Selective adsorption. Selective adsorption separates lithium using a lithium-ion sieve to absorb the dissolved lithium. ${ }^{103}$ Lithium-ion sieves are inorganic adsorbents that are extremely selective for lithium in a lithium-containing solution and originate from the technology used to extract lithium from solutions such as lithium brines. As lithium is the smallest metal ion, lithium-ion sieves use a vacancy to allow only lithium ions. Lithium manganese oxide has the highest selectivity, capacity, and stability among the inorganic solvents. In addition, it has low toxicity, which makes it the most commonly used material. Wang et al. leached lithium from lithium-ion batteries using an $\mathrm{NH}_{3}-\mathrm{H}_{2} \mathrm{O}-\mathrm{NH}_{4} \mathrm{HCO}_{3}$ solution with $\mathrm{H}_{2} \mathrm{O}_{2}{ }^{103}$ A manganese-type lithium-ion sieve was used to selectively adsorb lithium with the leached $\mathrm{Li}$, Co, and Ni solutions. The lithium-adsorbed lithium-ion sieve was separated and dissolved in $\mathrm{HCl}$. Then, $\mathrm{NaOH}$ and $\mathrm{Na}_{2} \mathrm{CO}_{3}$ were added to separate $\mathrm{Li}_{2} \mathrm{CO}_{3}$. This is a simple method using lithium-ion selective sieves and allows for low contamination; however, spinel-structured manganese-type lithium-ion sieves are very costly and require an additional leaching process to separate the lithium combined with $\mathrm{MnO}_{2}$.

Generally, the hydrometallurgy method guarantees high recovery rates and does not require additional equipment, making it quite popular in the laboratory and the method closest to commercialization. However, this method requires a high volume of acid and base for leaching (proportional to the lithium-ion battery), which can incur additional chemical costs. In addition, the backend costs of disposing the used solutions can be high. Table 5 shows different hydrometallurgy methods, lithium extraction conditions, and results, with a focus on studies that resulted in the production of the final compound after leaching.

\subsection{Electrochemical extraction}

Electrochemical extraction methods separate lithium from pretreated active materials using a lithium-selective transmissive membrane. This method extracts lithium from the powder state by putting the active material powder from the pre-treated waste lithium-ion battery in water and separating the lithium using a Li-ion conductive ceramic solid electrolyte. When the pre-treated active material is placed in water, the lithium in the powdered cathode does not dissolve, whereas lithium in the anode dissolves in water to form $\mathrm{LiOH}(\mathrm{aq})$. During charging, the dissolved and undissolved lithium can be separated via the solid ceramic electrolyte to form lithium metal. When charging occurs, the $\mathrm{Li}^{+}$dissolved in water can be separated by the oxygen evolution reaction (OER) (eqn (8)).

$$
2 \mathrm{LiOH} \rightarrow 2 \mathrm{Li}^{+}+2 \mathrm{e}^{-}+1 / 2 \mathrm{O}_{2}+\mathrm{H}_{2} \mathrm{O}
$$


Table 5 Summary of condition and residue parameters of hydrometallurgy processes of waste LIBs investigated in the literature

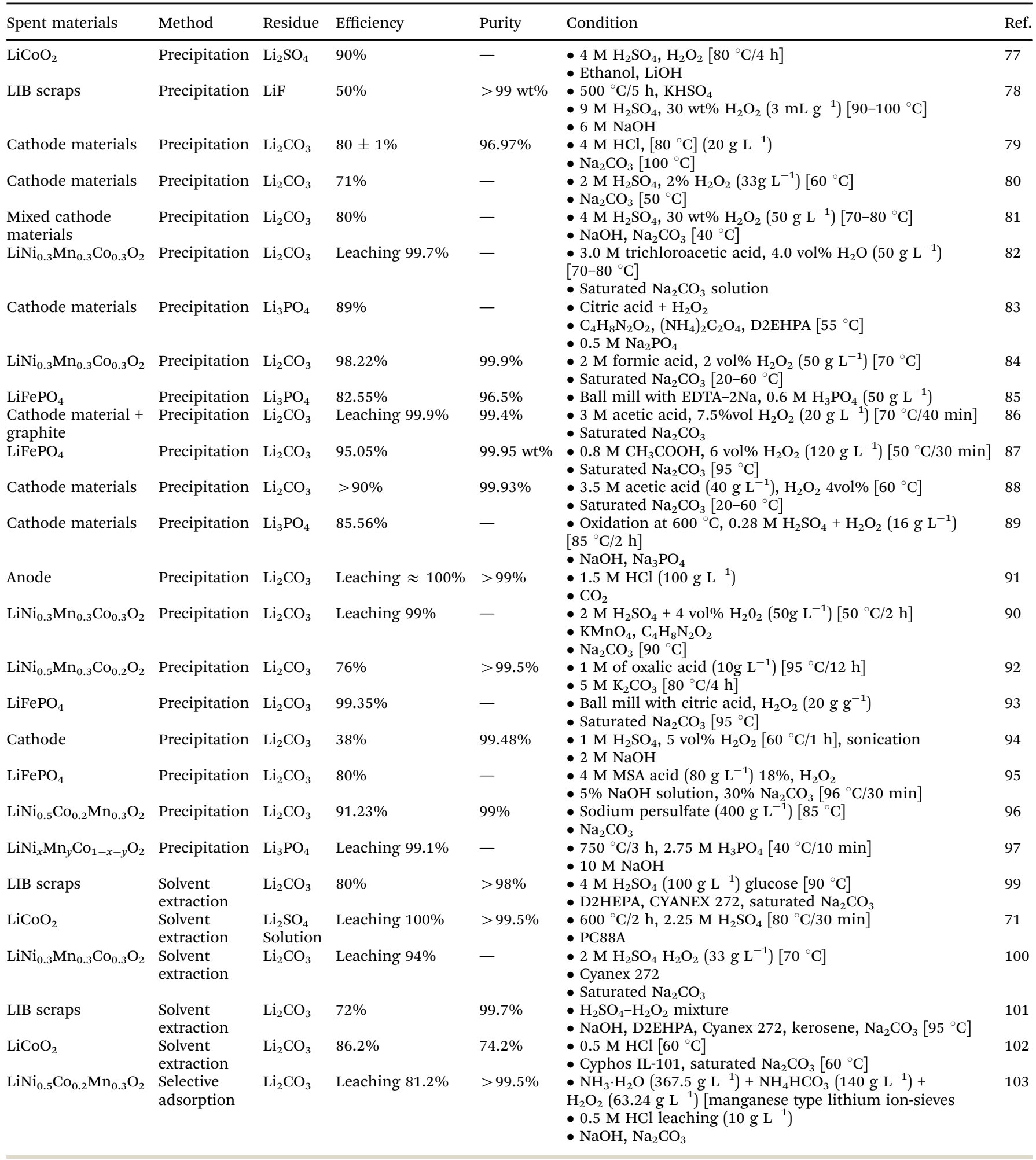

The undissolved $\mathrm{Li}^{+}$in the cathode powder can be separated by the same reaction as that of delithiation in the cathode material (eqn (9) and (10))

$$
\begin{gathered}
\mathrm{LiMO}_{2} \rightarrow \mathrm{Li}^{+}+\mathrm{e}^{-}+\mathrm{MO}_{2}(\mathrm{M}=\mathrm{Co}, \mathrm{Mn}, \mathrm{Ni}) \\
\mathrm{LiFePO}_{4} \rightarrow \mathrm{Li}^{+}+\mathrm{e}^{-}+\mathrm{FePO}_{4}
\end{gathered}
$$

The charging potential differs depending on the type of cathode material in the waste. When the active material is placed in water, the aqueous solution becomes a strong base owing to the influence of LiOH. The OER reaction during charging differs in operating voltage depending on the $\mathrm{pH}$, and in strongly basic conditions $(\mathrm{pH}>11)$, the OER reaction 
occurs below $3.6 \mathrm{~V}^{104}$ In the case of the $\mathrm{LiFePO}_{4}$ cathode powder, the delithiation reaction potential is $3.5 \mathrm{~V}$, which is lower than the voltage of the OER reaction in the strong base, and $\mathrm{Li}^{+}$is directly extracted from the cathode powder. However, for $\mathrm{LiCoO}_{2}$ (3.9 V), $\mathrm{LiMn}_{2} \mathrm{O}_{4}(4.0 \mathrm{~V})$, and $\mathrm{LiNi}_{0.3} \mathrm{Mn}_{0.3} \mathrm{Co}_{0.3} \mathrm{O}_{2}$ (3.7 V), because the delithiation potential is higher than that of the strong base OER reaction, $\mathrm{Li}^{+}$extraction from the solution occurs first, rather than from the cathode powder. However, during charging, the $\mathrm{pH}$ of the aqueous solution decreases because of the characteristics of the OER reaction, and the operating voltage of the OER reaction gradually increases. When the potential of the OER reaction exceeds that of the cathode powder material, $\mathrm{Li}^{+}$extraction from the powder becomes possible. Through this OER reaction and the reaction for each cathode material, $\mathrm{Li}^{+}$can be extracted and separated from both solution and powder, and when $\mathrm{Li}^{+}$can no longer be extracted, the charging of the system is automatically completed.

After charging, the separated $\mathrm{Li}^{+}$is discharged to water, passes through another ceramic solid electrolyte, and undergoes an oxygen reduction reaction (ORR) with water and electrons to form an aqueous $\mathrm{LiOH}$ solution. $\mathrm{LiOH}$ is a strong base that is used for $\mathrm{CO}_{2}$ capture because it is highly reactive with $\mathrm{CO}_{2}$ forming $\mathrm{Li}_{2} \mathrm{CO}_{3}$ (Fig. 9). The formation of $\mathrm{Li}_{2} \mathrm{CO}_{3}$ can be expressed as follows (eqn (11) and (12)):

$$
\begin{gathered}
2 \mathrm{Li}^{+}+2 \mathrm{e}^{-}+1 / 2 \mathrm{O}_{2}+\mathrm{H}_{2} \mathrm{O} \rightarrow 2 \mathrm{LiOH} \\
2 \mathrm{LiOH}+2 \mathrm{CO}_{2} \rightarrow 2 \mathrm{Li}_{2} \mathrm{CO}_{3}+\mathrm{H}_{2} \mathrm{O}
\end{gathered}
$$

Electrochemical extraction is a technology that can afford $\mathrm{Li}_{2} \mathrm{CO}_{3}$ powder without the need for drying or precipitation. When the system is continuously discharged, $\mathrm{Li}_{2} \mathrm{CO}_{3}$ powder precipitates naturally. When discharge occurs, the concentration of $\mathrm{Li}^{+}$in the water increases gradually, followed by an increase in the concentration of $\mathrm{Li}_{2} \mathrm{CO}_{3}$. In addition, owing to the ORR, $\mathrm{H}_{2} \mathrm{O}$ is consumed and the concentration of $\mathrm{Li}_{2} \mathrm{CO}_{3}$ increases relative to the decrease in the quantity of the solvent. This leads to the natural precipitation of $\mathrm{Li}_{2} \mathrm{CO}_{3}$.
An electrochemical system was developed to separate lithium from the cathode, anode, and electrolyte from a discarded lithium-ion battery. ${ }^{105}$ This device uses a $\mathrm{Li}_{1+x+y} \mathrm{Ti}_{2-x} \mathrm{Al}_{x} \mathrm{P}_{3-y} \mathrm{Si}_{y} \mathrm{O}_{12}$ solid electrolyte that transmits lithium selectively and has physically separated liquid cathode and anode parts. The liquid cathode contained $\mathrm{LiFePO}_{4}, \mathrm{Li}_{x} \mathrm{C}_{6}$, and $1 \mathrm{M} \mathrm{LiPF}_{6}-\mathrm{EC}$ :DMC. Through electrochemical charging, lithium is separated and passed through the solid electrolyte to separate the lithium metal from the anode. In later studies, an advanced system was developed to separate lithium from $\mathrm{LiFePO}_{4}, \mathrm{LiMn}_{2} \mathrm{O}_{4}$, and $\mathrm{LiNi}_{0.3} \mathrm{Mn}_{0.3} \mathrm{Co}_{0.3} \mathrm{O}_{2}$ cathode powders. ${ }^{106}$ This system is composed of a waste cathode, harvesting anode, and recycling cathode, and each compartment is physically separated by a solid electrolyte. In the actual electrochemical system, a polymer film was used as the body of the system, solid electrolytes were attached to both sides, and an anode was placed in the middle to produce a harvesting anode. A harvesting anode was inserted between the waste cathode and recycling cathode to separate the battery into three compartments (Fig. 10a). The fabricated electrochemical lithium extraction system can extract lithium through electrochemical charging and discharging, as shown in Fig. 10b. The cathode powder from the lithium-ion battery contacted the waste cathode current collector of the waste cathode. During electrochemical charging, $\mathrm{Li}^{+}$extraction from the cathode powder occurs, passing through the solid electrolyte, followed by an electrochemical reaction at the harvesting anode to form metallic lithium (Fig. 10c). By discharging the separated lithium from the harvesting anode to the distilled water, $\mathrm{Li}_{2} \mathrm{CO}_{3}$ can be formed via a reaction with water, oxygen, and $\mathrm{CO}_{2}$ (Fig. 10c). Actual discarded lithium-ion batteries were tested using this system and it was proved that $\mathrm{Li}_{2} \mathrm{CO}_{3}$ can be recycled.

The electrochemical extraction method can extract $75-95 \%$ of lithium from active material powder during recycling, and it can extract not only $\mathrm{Li}_{2} \mathrm{CO}_{3}$ compounds but also lithium metal if necessary. The recycled lithium metal was analyzed using inductively coupled plasma analysis and showed a purity of $99 \%$. In an additional experiment, the purity of the final

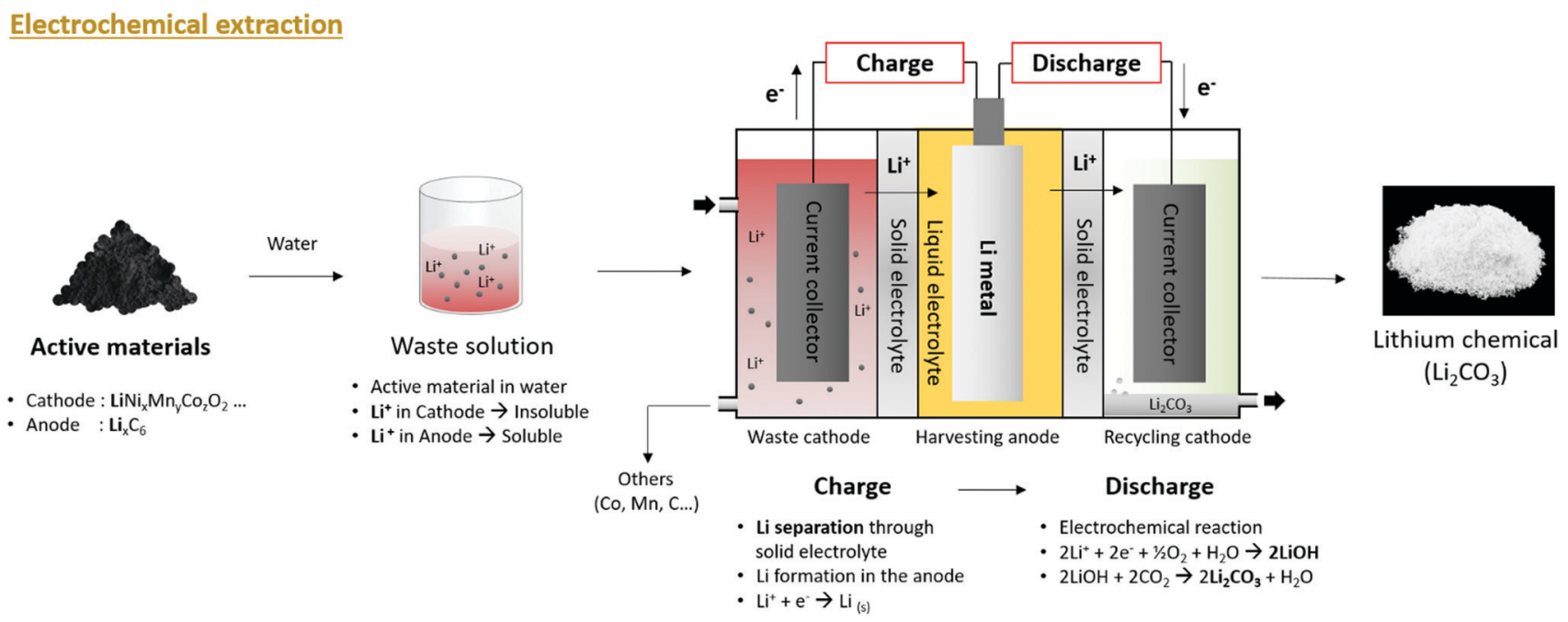

Fig. 9 Overall schematic of lithium recycling from pre-treated waste LIB components by electrochemical extraction process. 


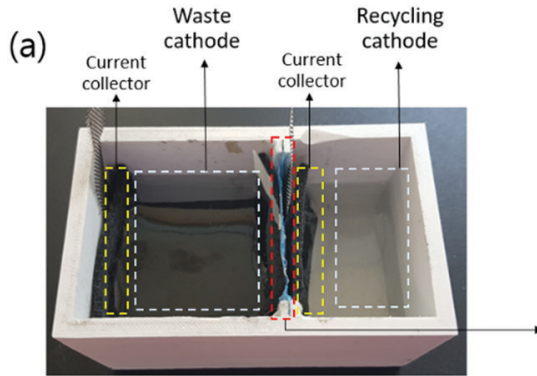

Electrochemical Li extraction system

(b)

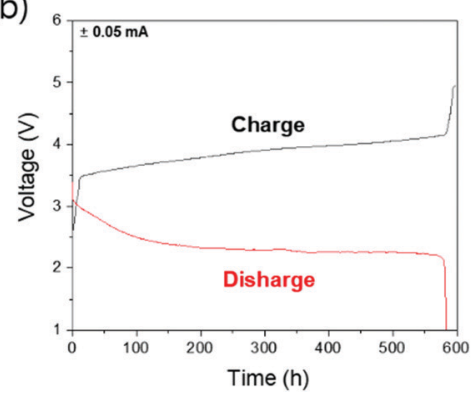

(c)

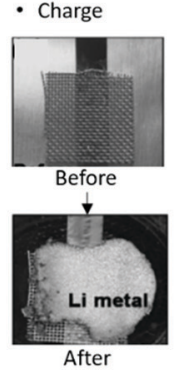

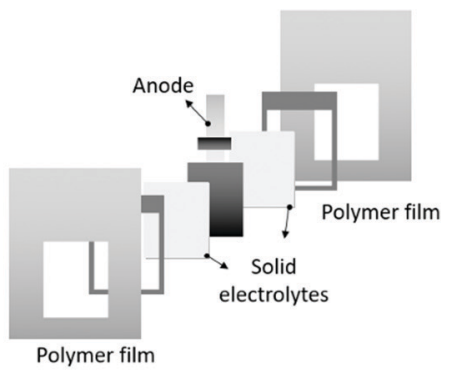

Polymer film

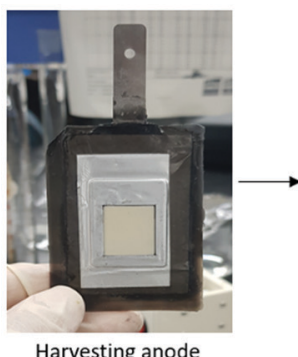

- Discharge

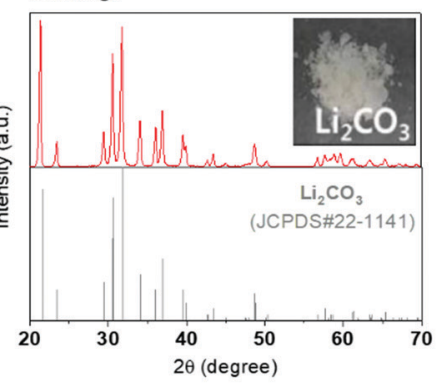

Fig. 10 (a) Prismatic design of electrochemical Li-extraction process.

(b) Charge and discharge voltage profile during Li-extraction. (c) Li metal formation after charging and $\mathrm{Li}_{2} \mathrm{CO}_{3}$ formation after discharging.

material, $\mathrm{Li}_{2} \mathrm{CO}_{3}$, was analyzed via the acid-base titration method (Standardization Administration of the People's Republic of China (SAC) method), and the purity was $99.6 \%$.

This method only requires charging and discharging and does not require additional chemical compounds or an increase in temperature. With this system, lithium-ion batteries can be recycled in an environment-friendly manner using only water. In addition, by using a special solid electrolyte that allows only lithium to pass through, high-purity lithium can be separated and be used as an energy storage system. However, this method requires the setting up of an electrochemical system and solid electrolyte and has only been proven on a laboratory scale; further research is required before it can be scaled up for commercialization. Table 6 lists the research methods using electrochemical extraction. To scale up the system, research is being conducting to increase the efficiency and speed of Li extraction by designing a cell structure, expanding the area of the solid electrolyte and stacking the system. In addition, since this electrochemical lithium extraction method can extract lithium from $\mathrm{LiOH}$, as well as other lithium solutions in any form, studies are being conducted not only on Liion batteries but also on Li-containing glasses.

Three methods to produce lithium compounds from a pretreated lithium-ion battery have been discussed: pyrometallurgy, hydrometallurgy, and electrochemical extraction. These techniques are still under research, and the methods can be combined to overcome their respective drawbacks.

Table 7 lists quantitative metrics on the pyrometallurgy, hydrometallurgy, and electrochemical lithium recycling methods. These metrics include the recycling efficiency, additional cost of chemicals, operating temperature, complexity, pollutant production, and commercialization level. The methods only consider the lithium extraction process after pre-treatment, as the pre-treatment methods can vary depending on the lithiumion battery type and quantity. The lithium recycling efficiency and purity is obtained from available literature regarding the methods. For the additional cost of chemicals, the price was normalized per kilogram of discarded active material powder, after considering the required amount and price. ${ }^{107-109}$ Operating temperature considers the temperature range needed for lithium extraction. For complexity, the essential steps for each method are examined. Pollutants include different polluting materials that can result from each recycling process, and the level of commercialization separates the methods that already have been commercialized and methods that are only developed at a laboratory level.

Fig. 11 is based on Table 7 and describes the characteristics of each method using a spider plot. The image shows the relative magnitudes of the different metrics involved in lithium extraction.

Table 6 Summary of condition and residue parameters of electrochemical recycling processes of waste LIBs investigated in the literature

\begin{tabular}{llllr}
\hline Spent materials & Residue & Efficiency & Purity & Condition \\
\hline LiFePO $_{4}, \mathrm{C}_{6}, \mathrm{LiPF}_{6}$ & Li metal & - & - & Ref. \\
Cathode powders, LIB scraps & Li metal, $\mathrm{Li}_{2} \mathrm{CO}_{3}$ & $75-92 \%$ & $99 \%$ (metal) & Current $0.1 \mathrm{~mA} \mathrm{~cm}^{-2}$ \\
Current $0.05 \mathrm{~mA}$ & 105
\end{tabular}


Table 7 Quantitative calculation table for each factors of lithium recycling technologies from waste LIBs

\begin{tabular}{|c|c|c|c|c|c|c|c|}
\hline $\begin{array}{l}\text { Li recycling } \\
\text { method }\end{array}$ & $\begin{array}{l}\text { Recycle } \\
\text { efficiency } \\
(\%)\end{array}$ & $\begin{array}{l}\text { Purity } \\
(\%)\end{array}$ & $\begin{array}{l}\text { Additional chemical } \\
\text { cost }\left(\mathrm{S} \mathrm{kg}^{-1}\right)\end{array}$ & $\begin{array}{l}\text { Temperature } \\
\left({ }^{\circ} \mathrm{C}\right)\end{array}$ & Complexity & $\begin{array}{l}\text { Potential } \\
\text { pollutions }\end{array}$ & $\begin{array}{l}\text { Commercial } \\
\text { readiness }\end{array}$ \\
\hline Pyrometallurgy & $80-98.9$ & 98-99.95 & $\begin{array}{l}1.894 \mathrm{~m}^{-3} \text { (flowing gas }\left(\mathrm{N}_{2}\right) \text {, } \\
\text { depends on furnace size) }\end{array}$ & $650-1700$ & $\begin{array}{l}2 \text { Steps } \\
\text { - Oxygen free roasting } \\
\text { - Wet magnetic } \\
\text { separation }\end{array}$ & $\begin{array}{l}\text { Volatile organic } \\
\text { compounds }\end{array}$ & $\begin{array}{l}\text { Commercialized } \\
\text { [Accurec } \mathrm{GmbH}]\end{array}$ \\
\hline $\begin{array}{l}\text { Hydrometallurgy } \\
\text { [precipitation] }\end{array}$ & $76-98.2$ & $96.5-99.97$ & $3.18\left(\mathrm{CH}_{2} \mathrm{O}_{2}, \mathrm{H}_{2} \mathrm{O}_{2}\right.$ etc. $)$ & $50-100$ & $\begin{array}{l}3 \text { Steps } \\
\text { - Leaching } \\
\text { - Other metal } \\
\text { precipitation } \\
\text { (pH adjustment) } \\
\text { - Li precipitation }\end{array}$ & $\begin{array}{l}\text { Inorganic } \\
\text { waste } \\
\text { Acidic waste }\end{array}$ & $\begin{array}{l}\text { Commercialized } \\
\text { [TOXCO (Retriev)] }\end{array}$ \\
\hline $\begin{array}{l}\text { Hydrometallurgy } \\
\text { [solvent extraction] }\end{array}$ & $72-86.2$ & $74.2-99.7$ & $73.3\left(\mathrm{H}_{2} \mathrm{SO}_{4}, \mathrm{PC} 88 \mathrm{~A}\right.$ etc. $)$ & $60-90$ & $\begin{array}{l}\text { 4 Steps } \\
\text { - Leaching } \\
\text { - Solvent extraction } \\
\text { - Solution separation } \\
\text { - Precipitation }\end{array}$ & $\begin{array}{l}\text { Inorganic waste } \\
\text { Organic waste } \\
\text { Acidic waste }\end{array}$ & On research \\
\hline $\begin{array}{l}\text { Hydrometallurgy } \\
\text { [selective adsorption }\end{array}$ & $\begin{array}{l}\text { Leaching } \\
81.2\end{array}$ & $>99.5$ & $14.9\left(\mathrm{NH}_{3}, \mathrm{HCl}\right.$ etc. & 30 & $\begin{array}{l}\text { 4 Steps } \\
\text { - Leaching } \\
\text { - Sieve adsorption } \\
\text { - Sieve leaching } \\
\text { - Precipitation }\end{array}$ & Acidic waste & On research \\
\hline $\begin{array}{l}\text { Electrochemical } \\
\text { extraction }\end{array}$ & $75-92$ & $\begin{array}{l}>99 \\
(\text { metal })\end{array}$ & - & Room temp. & $\begin{array}{l}2 \text { Steps } \\
\text { - Charging } \\
\text { - Discharging }\end{array}$ & - & On research \\
\hline
\end{tabular}

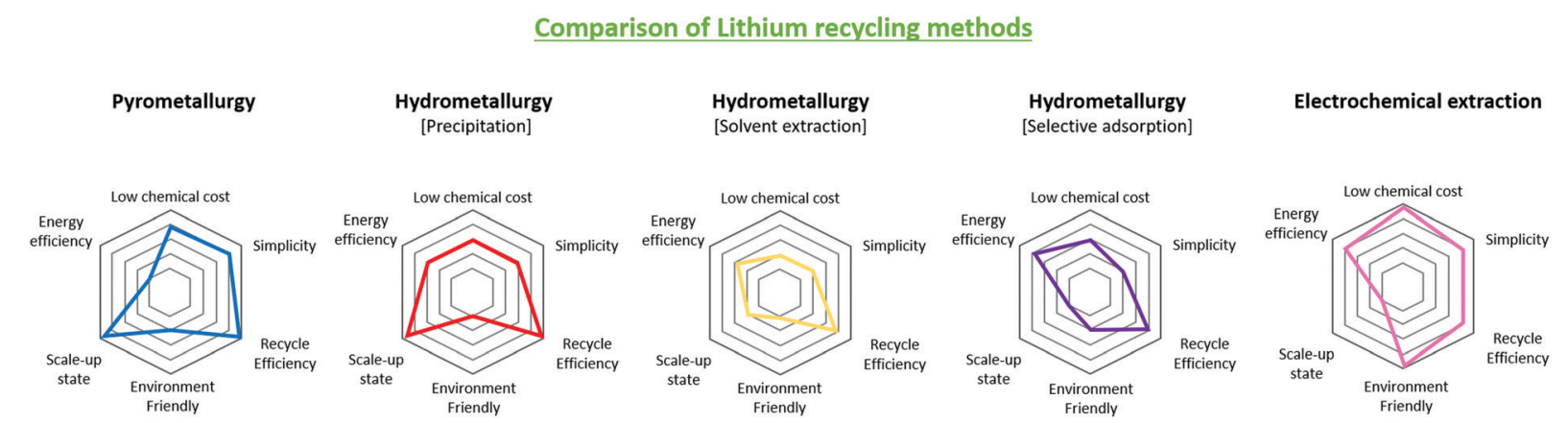

Fig. 11 Performance and industrial comparisons of lithium recycling technologies from waste LIBs, pyrometallurgy, hydrometallurgy and electrochemical extraction.

\section{Current state of lithium recycling}

With the dawn of the era of Battery of Things (BoT), emerging applications other than EVs and ESSs are causing a significant hike in the demand for lithium-ion batteries. The growth of the markets has also resulted in a steep increase in the quantity of discarded lithium-ion batteries. As lithium resources are limited, this trend is expected to cause a shortage of lithium in the near future. This has led nations to create policies to regulate lithium-ion battery disposal, and research institutes and companies, aligning with policy interests, are focusing on lithium recycling technology. Worldwide, companies such as Umicore, Sumitomo-sony, DK recycling und Roheisen $\mathrm{GmbH}$, and SNAM, recycle batteries using the pyrometallurgy and hydrometallurgy methods explained above. ${ }^{110,111}$ However, these companies have focused on recycling $\mathrm{Co}$ and $\mathrm{Ni}$, rather than lithium. Conversely, Accurec and Retriev (TOXCO) use pyrometallurgy and hydrometallurgy methods to produce lithium compounds from disposed lithium-ion batteries.
Accurec pre-treats the battery mechanically to separate the plastic, followed by vacuum thermal treatment to remove the electrolyte and solvent. The material is then crushed, sieved, and separated (magnetically and with air) to separate $\mathrm{Al}, \mathrm{Fe}, \mathrm{Cu}$, and plastic. The pre-treated material then undergoes pyrometallurgy treatments, namely, reduction to separate Co and Mn, followed by hydrometallurgy and acid leaching to precipitate $\mathrm{LiCl} .{ }^{112}$

Retriev's pre-treatment processes include the use of liquid nitrogen in the cryo-milling process (at $-196{ }^{\circ} \mathrm{C}$ ) followed by the use of a hammer mill to crush the material. Subsequently, $\mathrm{Cu}$, $\mathrm{Co}$, and $\mathrm{Al}$ were separated on a shaker table, and the remaining cathode and anode material were processed in a filter tank and carbon filter press to remove the metal oxide and carbon. $\mathrm{Na}_{2} \mathrm{CO}_{3}$ was added to the solution to precipitate $\mathrm{Li}_{2} \mathrm{CO}_{3} \cdot{ }^{13,114}$

The last decade has seen a global rise in the interest in lithium recycling. However, issues remain regarding the means to commercialize and make the process more environmentally friendly. According to the UNEP report on recycling rates, the 
lithium-ion battery recycling rate in the EU is less than $5 \%$, and less than $1 \%$ of lithium is recycled. ${ }^{115-118}$

\section{Future directions for lithium recycling technologies}

Given these circumstances, each method of lithium recycling must be developed for commercialization to create a better and more sustainable lithium cycle. Research and development in this field must take the directions indicated below for a more vibrant lithium recycling market (Fig. 12):

(1) Although the increase in the demand for lithium is due to lithium-ion batteries, technological development to extract lithium from other products is needed. There is almost no research on the extraction of lithium from non-batteries. Because $35 \%$ of the lithium is used for glass, grease, and casting (as of 2019), more attention should be paid to the recycling of lithium from these products. The best option could be to leverage the technologies developed for recycling lithium-ion batteries to extract lithium from other waste lithium sources. Overall, this positively affects the entire lithium cycle.

(2) Even if lithium materials are collected for recycling in an organized manner, it is difficult to process them simultaneously.
For batteries, the materials for the cathode, anode, and electrolytes, as well as the size of the batteries, vary widely. Processing them simultaneously holds the risk of problems such as explosions. A policy is needed to categorize or automatically process the disposed lithium material. In addition, it is important to pre-treat lithiumcontaining materials to increase the efficiency of lithium recycling. With a safe and environmentally friendly pre-treatment method, considerable quantities of lithium materials can be processed to significantly increase the speed of the lithium cycle.

(3) Currently, the techniques that are widely commercialized or researched are also environmentally harmful. Lithium recycling technology should not only mitigate lithium scarcity but also reduce waste to prevent environmental pollution. However, most currently developed recycling methods produce pollutants. This includes harmful gases created by the heat treatment of lithium waste and the acids, bases, and organic solvents used for leaching. This also leads to additional expenses. The extra costs and procedures can hinder the commercialization of the process. Thus, substantial consideration should be given to streamlining the process to minimize waste products or finding ways to reuse the waste products from these processes.

(4) For such a process, economics cannot be ignored. If the purchasing cost is lower than the recycling cost, recycling would not be economically appropriate or viable. Current methods

\section{Future requirements for Li recycling}

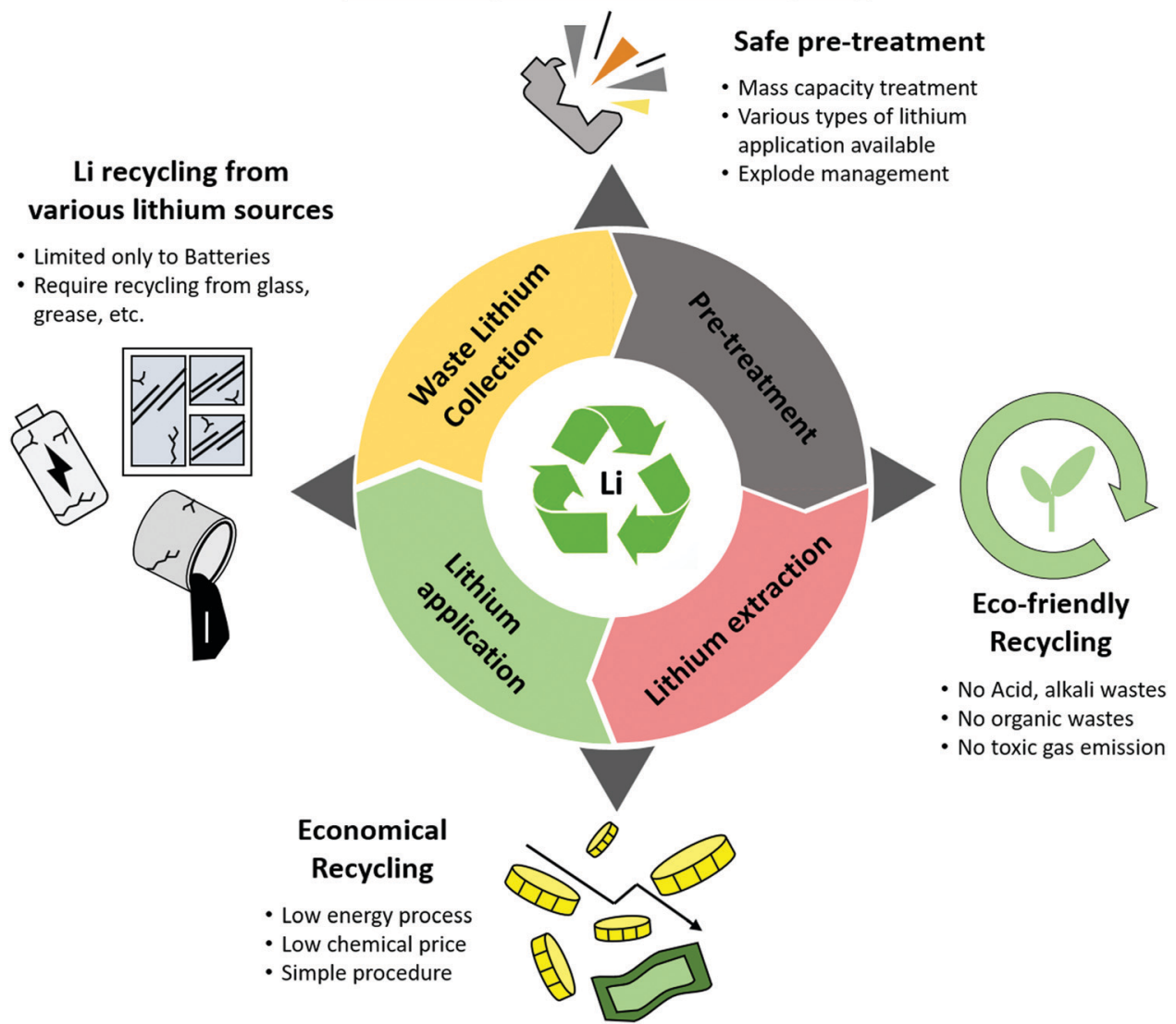

Fig. 12 Future requirements for waste LIB recycling: recycling from various lithium sources, safe treatment, eco-friendly recycling, economical recycling. 
that use acids or bases or operate at high temperatures are usually costly and energy-intensive. The involvement of more chemicals in the process will increase the cost of the process. The quantities of acids and bases required for lithium recycling are substantially greater than that of the recycled product, which is economically disadvantageous. Thus, methods to reuse the acids and bases, or to lower the operating temperature, must be developed to minimize the cost and energy required to recycle lithium. If an economically viable method emerges, this will accelerate interest in the development of lithium recycling technologies.

\section{Conclusions}

These future efforts will allow lithium to be an eco-friendlier and economical driving force for future technologies by creating a more natural recycling cycle, similar to those of other elements. In addition to the development of lithium recycling technologies, global awareness regarding lithium scarcity is important, and perspectives of sellers, developers, and recycling agents in this matter should be improved. Moreover, government-level policy interests and support are crucial for a more sustainable lithium economy.

\section{Conflicts of interest}

There are no conflicts to declare.

\section{Acknowledgements}

This work was supported by the Human Resources Program in Energy Technology of the Korea Institute of Energy Technology Evaluation and Planning (KETEP), which was granted financial resources from the Ministry of Trade, Industry \& Energy, Republic of Korea (20194010201890). Also, this material is based upon work supported by the Ministry of Trade, Industry \& Energy (MOTIE, Korea) under Industrial Technology Innovation Program. No. 20003877, 'Development of eco-friendly electrochemical recycling system for production of high purity (>99.5\%) lithium and lithium compounds.'

\section{Notes and references}

1 H. Tong, Q. Zhou, B. Zhang, X. Wang, Y. Yao, Z. Ding, H. Chen, J. Zheng and W. Yu, Eng. Sci., 2019, 8, 25.

2 R. Li, C. Lin, N. Wang, L. Luo, Y. Chen, J. Li and Z. Guo, Adv. Compos. Hybrid Mater., 2018, 1, 440.

3 C. Hou, B. Wang, V. Murugadoss, S. Vupputuri, Y. Chao, Z. Guo, C. Wang and W. Du, Eng. Sci., 2020, 11, 19.

4 M. Idrees, L. Liu, S. Batool, H. Luo, J. Liang, B. Xu, S. Wang and J. Kong, Eng. Sci., 2019, 6, 64.

5 Q. Zhang, J. Dai, M. Liao, T. Duan and W. Yao, Eng. Sci., 2019, 7, 43.

6 C. Hou, J. Hou, H. Zhang, Y. Ma, X. He, W. Geng and Q. Zhang, Eng. Sci., 2020, 11, 36.
7 C. Hou, W. Yang, X. Xie, X. Sun, J. Wang, N. Naik, D. Pan, X. Mai, Z. Guo, F. Dang and W. Du, J. Colloid Interface Sci., 2021, 596, 396.

8 Sociedad Química y Minera de Chile S.A., Annual Report 2019, 2020.

9 M. Garside, Total global consumption of lithium from 2008 to 2016, 2019.

10 Lithium resources, http://chem230.wikia.com/wiki/Lithium_ Resources (accessed on 05 April 2021).

11 H. Vikström, S. Davidsson and M. Höök, Appl. Energy, 2013, 110, 252.

12 M. Garside, Distribution of lithium end-usage worldwide in 2019 by area of application, 2020, https:/www.statista.com/ statistics/268787/lithium-usage-in-the-world-market/ (accessed on 05 April 2021).

13 P. W. Gruber, P. A. Medina, G. A. Keoleian, S. E. Kesler, M. P. Everson and T. J. Wallington, J. Ind. Ecol., 2011, 15(5), 760.

14 TALISON LITHIUM, Lithium, https://www.talisonlithium. com/lithium (accessed on 05 April 2021.

15 G. E. Totten, S. R. Westbrook and R. J. Shah, Fuels and lubricants handbook: technology, properties, performance, and testing, ASTM Int., 2003, ch. 22, p. 559.

16 Y. Q. Lu, G. D. Zhang, M. F. Jiang, H. X. Liu and T. Li, Mater. Sci. Forum, 2011, 675, 877.

17 R. K. Bansal, 1996, 192, ISBN 978-0-7637-0665-4.

18 P. Meshram, B. D. Pandey and T. R. Mankhand, Hydrometallurgy, 2014, 150, 192.

19 G. Liu, Z. Zhao and A. Ghahreman, Hydrometallurgy, 2019, 187, 81.

20 J. F. Labbé and G. Daw, Panorama $2011 d u$ marché $d u$ lithium; Rapport public 2012, BRGM/RP-61340-FR, BRGM, Orléans, France, 2012.

21 S. H. Mohr, G. M. Mudd and D. Giurco, Minerals, 2012, 2, 65.

22 D. E. Garrett, Handbook of Lithium and Natural Calcium Chloride: Their Deposits, Processing, Uses and Properties, 1st edn, Elsevier, 2004.

23 A. Yaksic and J. E. Tilton, Resour. Policy, 2009, 34, 185.

24 P. Chen, S. Tang, H. Yue, C. Liu, C. Li and B. Liang, Ind. Eng. Chem. Res., 2017, 56, 5668.

25 W. C. Bauman and J. L. Burba, Google Patents, US6280693B1, 2001.

26 X. Liu, M. Zhong, X. Chen and Z. Zhao, Hydrometallurgy, 2018, 176, 73.

27 Saltworks, Lithium Brine Extraction Technologies \& Approaches, June 8th, 2018, https://www.saltworkstech. com/articles/lithium-brine-extraction-technologies-andapproaches/ (accessed on 05 April 2021).

28 Roskill Information Services Ltd., "The Economics of Lithium", Eleventh Edition, 2009.

29 Y. Zhang, Y. Hu, L. Wang and W. Sun, Miner. Eng., 2019, 139, 105868.

30 K. Pennell, How Does Lithium Mining Work? 2018, https:// blog.grabcad.com/blog/2018/02/20/how-does-lithium-miningwork/ (accessed on 05 April 2021). 
31 V. Flexer, C. F. Baspineiro and C. I. Galli, Sci. Total Environ., 2018, 639, 1188.

32 R. F. Service, Seawater could provide nearly unlimited amounts of critical battery material, Science, 2020, https:// www.sciencemag.org/news/2020/07/seawater-could-providenearly-unlimited-amounts-critical-battery-material/ (accessed on 30 April 2021).

33 M. Garside, Average lithium carbonate price from 2010 to 2019 (in U.S. dollars per metric ton), 2020, https://www. statista.com/statistics/606350/battery-grade-lithium-carbonateprice/ (accessed on 05 April 2021).

34 Lithium-Ion Battery Market by Type, Power Capacity, Industry, Voltage, Region-Global Forecast to 2025, 2020.

35 Y. Ding, Z. P. Cano, A. Yu, J. Lu and Z. Chen, Electrochem. Energy Rev., 2019, 2, 1.

36 How much Lithium is in a Li-Ion Vehicle Battery, 2017, https:/www.linkedin.com/pulse/how-much-lithium-li-ionvehicle-battery-paul-martin/ (accessed on 05 April 2021).

37 U.S. Geological Survey, Mineral Commodity Summaries, January 2020.

38 Altura Lithium, New Significant Supply to the Battery market in 2018, 2018, 32, https://alturamining.com/wp-content/ uploads/2018/07/2018-06-27-Investor-Pres-June-2018-updated. pdf/, (accessed on 30 April 2021).

39 Projection of total worldwide lithium demand from 2018 to 2025 (in 1000 metric tons of lithium carbonate equivalent), 2019.

40 C. Admin, How Often Should I Charge My Phone To Prolong The Battery Life? 2020, https://charbycharge.com/ how-often-should-i-charge-my-phone-to-prolong-the-batterylife/ (accessed on 05 April 2021).

41 P. Haidl, A. Buchroithner, B. Schweighofer, M. Bader and H. Wegleiter, Sustainability, 2019, 11, 6731.

42 J. Svarc, Lead-Acid Vs Lithium-Ion Batteries, 2019, https://www. cleanenergyreviews.info/blog/simpliphi-pylontech-narada-baelead-acid-battery (accessed on 05 April 2021).

43 Lead Acid Battery working - Lifetime Study, http://www. power-thru.com/documents/The\%20Truth\%20About\%20 Batteries\%20-\%20POWERTHRU\%20White\%20Paper.pdf (accessed on 05 April 2021).

44 Features of sealed lead acid batteries, https://www.power-sonic. $\mathrm{com} / \mathrm{blog} /$ features-of-sealed-lead-acid-batteries/ (accessed on 04.05.2021).

45 D. L. Thompson, J. M. Hartley, S. M. Lambert, M. Shiref, G. D. J. Harper, E. Kendrick, P. Anderson, K. S. Ryder, L. Gaines and A. P. Abbott, Green Chem., 2020, 22, 7585.

46 L. An, Recycling of Spent Lithium-Ion Batteries, Processing Methods and Environmental Impacts, 2019.

47 M. Jacoby, Chem. Eng., 2019, 97(28), https://cen.acs.org/ materials/energy-storage/time-serious-recycling-lithium/97/ i28 (accessed on 05 April 2021).

48 C. Pillot, Presented at the 31st International Battery Seminar \& Exhibit, Fort Lauderdale, FL, USA, 2017.

49 D. Hauck and M. Kurrat, Overdischarging Lithium-Ion Batteries, Springer, 2018.
50 A. Kwade and J. Diekmann, Recycling of Lithium-Ion Batteries; The LithoRec Way, Sustainable Production, Life Cycle Engineering and Management, 2018, ch. 4, p. 53.

51 J. S. Stewart, A. A. Reguera, A. Greszta, J. Marco, M. Masood, R. Sommerville and E. Kendrick, Sustainable Mater. Technol., 2019, 22, e00110.

52 T. Zhang, Y. He, F. Wang, L. Ge, X. Zhu and H. Li, Waste Manage., 2014, 34, 1051.

53 D. A. Bertuol, C. Toniasso, B. M. Jimenez, L. Meili, G. L. Dotto, E. H. Tanabe and M. L. Aguiar, J. Power Sources, 2015, 275, 62.

54 F. Pagnanelli, E. Moscardini, P. Altimari, T. A. Atia and L. Toro, Waste Manage., 2016, 51, 214.

55 X. Wang, G. Gaustad and C. W. Babbitt, Waste Manage., 2016, 51, 204.

56 F. Pagnanelli, E. Moscardini, P. Altimari, T. A. Atia and L. Toro, Waste Manage., 2017, 60, 706.

57 Y. Zhang, Y. He, T. Zhang, X. Zhu, Y. Feng, G. Zhang and X. Bai, J. Cleaner Prod., 2018, 202, 736.

58 L. Li, J. Ge, R. Chena, F. Wua, S. Chen and X. Zhang, Waste Manage., 2010, 30, 2615.

59 X. Chen and T. Zhou, Waste Manage. Res., 2014, 32(11), 1083.

60 L. P. He, S. Y. Sun, X. F. Song and J. G. Yu, Waste Manage., 2015, 46, 523.

61 X. Chen, C. Luo, J. Zhang, J. Kong and T. Zhou, ACS Sustainable Chem. Eng., 2015, 3, 3104.

62 L. Sun and K. Qiu, Waste Manage., 2012, 32, 1575.

63 P. Meshram, B. D. Pandey and T. R. Mankhand, Chem. Eng. J., 2015, 281, 418.

64 C. Hanisch, T. Loellhoeffel, J. Diekmann, K. J. Markley, W. Haselrieder and A. Kwade, J. Cleaner Prod., 2015, 108, 301.

65 Y. Yang, G. Huang, S. Xu, Y. He and X. Liu, Hydrometallurgy, 2016, 165, 390.

66 T. G. Maschler, B. Friedricha, R. Weyhe, H. Heegn and M. Rutz, J. Power Sources, 2012, 207, 173.

67 J. Li, G. Wang and Z. Xu, J. Hazard. Mater., 2016, 302, 97.

68 J. Xiao, J. Li and Z. Xu, Environ. Sci. Technol., 2017, 51, 11960.

69 J. Xiao, J. Li and Z. Xu, J. Hazard. Mater., 2017, 338, 124.

70 J. Hu, J. Zhang, H. Li, Y. Chen and C. Wang, J. Power Sources, 2017, 351, 192.

71 H. Dang, B. Wang, Z. Chang, X. Wu, J. Feng, H. Zhou, W. Li and C. Sun, ACS Sustainable Chem. Eng., 2018, 6, 13160.

72 S. Pindar and N. Dhawan, J. Oper. Manage., 2019, 71, 4483.

73 C. Pengb, F. Liu, Z. Wang, B. P. Wilson and M. Lundström, J. Power Sources, 2019, 415, 179.

74 S. Maroufi, M. Assefi, R. Khayyam and V. Sahajwalla, Sustainable Mater. Technol., 2020, 23, e00139.

75 S. Pindar and N. Dhawan, J. Therm. Anal. Calorim., 2020, DOI: 10.1007/s10973-020-10139-6.

76 J. Lin, L. Li, E. Fan, C. Liu, X. Zhang, H. Cao, Z. Sun and R. Chen, ACS Appl. Mater. Interfaces, 2020, 12, 18482.

77 S. Aktas, D. J. Fray, O. Burheim, J. Fenstad and E. Açma, Metallurgy, 2006, 115(2), 95. 
78 J. F. Paulino, N. G. Busnardo and J. C. Afonso, J. Hazard. Mater., 2008, 150, 843.

79 R. C. Wang, Y. C. Lin and S. H. Wu, Hydrometallurgy, 2009, 99, 194.

80 S. Zhu, W. He, G. Li, X. Zhou, X. Zhang and J. Huang, Trans. Nonferrous Met. Soc. China, 2012, 22, 2274.

81 H. Zou, E. Gratz, D. Apelian and Y. Wang, Green Chem., 2013, 15, 1183.

82 X. Zhang, H. Cao, Y. Xie, P. Ning, H. An, H. You and F. Nawaz, Sep. Purif. Technol., 2015, 150, 186.

83 X. Chen, T. Zhou, J. Kong, H. Fang and Y. Chen, Sep. Purif. Technol., 2015, 141, 76.

84 W. Gao, X. Zhang, X. Zheng, X. Lin, H. Cao, Y. Zhang and Z. Sun, Environ. Sci. Technol., 2017, 51, 1662.

85 Y. Yang, X. Zheng, H. Cao, C. Zhao, X. Lin, P. Ning, Y. Zhang, W. Jin and Z. Sun, ACS Sustainable Chem. Eng., 2017, 5, 9972.

86 S. Natarajan, A. B. Boricha and H. C. Bajaj, Waste Manage., 2018, 77, 455.

87 Y. Yang, X. Meng, H. Cao, X. Lin, C. Liu, Y. Sun, Y. Zhang and Z. Sun, Green Chem., 2018, 20, 3121.

88 W. Gao, J. Song, H. Cao, X. Lin, X. Zhang, X. Zheng, Y. Zhang and Z. Sun, J. Cleaner Prod., 2018, 178, 833.

89 S. Tao, J. Li, L. Wang, L. Hu and H. Zhou, Ionics, 2019, 25, 5643.

90 R. Sattar, S. Ilyas, H. N. Bhatti and A. Ghaffar, Sep. Purif. Technol., 2019, 209, 725.

91 Y. Yang, S. Song, S. Lei, W. Sun, H. Hou, F. Jiang, X. Ji, W. Zhao and Y. Hu, Waste Manage., 2019, 85, 529.

92 Q. Li, K. Y. Fung, L. Xu, C. Wibowo and K. M. Ng, Ind. Eng. Chem. Res., 2019, 58, 3118.

93 L. Li, Y. Bian, X. Zhang, Y. Yao, Q. Xue, E. Fan, F. Wu and R. Chen, Waste Manage., 2019, 85, 437.

94 C. H. Jo and S. T. Myung, J. Power Sources, 2019, 426, 259.

95 P. Yadav, C. J. Jie, S. Tan and M. Srinivasan, J. Hazard. Mater., 2020, 399, 123068.

96 W. Lv, Z. Wang, X. Zheng, H. Cao, M. He, Y. Zhang, H. Yu and Z. Sun, ACS Sustainable Chem. Eng., 2020, 8(13), 5165.

97 Y. Zhang, W. Wang, J. Hu, T. Zhang and S. Xu, ACS Sustainable Chem. Eng., 2020, 8, 15496.

98 P. Zhang, T. Yokoyama, O. Itabashi, T. M. Suzuki and K. Inoue, Hydrometallurgy, 1998, 47, 259.
99 G. Granata, E. Moscardini, F. Pagnanelli, F. Trabucco and L. Toro, J. Power Sources, 2012, 206, 393.

100 W. S. Chen and H. J. Ho, Metals, 2018, 8, 321.

101 T. A. Atia, G. Elia, R. Hahn, P. Altimari and F. Pagnanelli, J. Energy Chem., 2019, 35, 220.

102 L. Xu, C. Chen and M. L. Fu, Hydrometallurgy, 2020, 197, 105439.

103 H. Wang, K. Huang, Y. Zhang, X. Chen, W. Jin, S. Zheng, Y. Zhang and P. Li, ACS Sustainable Chem. Eng., 2017, 5, 11489.

104 A. G. Rajan and E. A. Carter, Energy Environ. Sci., 2020, 13, 4962 .

105 N. M. Asl, S. S. Cheah, J. Salim and Y. Kim, RSC Adv., 2012, 2, 6094.

106 H. Bae, S. M. Hwang, I. Seo and Y. Kim, J. Electrochem. Soc., 2016, 163(7), E199.

107 CEIC, https://www.ceicdata.com/ (accessed on 05 April 2021).

108 Chemical book, https://www.chemicalbook.com/ (accessed on 05 April 2021).

109 ECHEMI.com, https://www.echemi.com/ (accessed on 05 April 2021).

110 C. Liu, J. Lin, H. Cao, Y. Zhang and Z. Sun, J. Cleaner Prod., 2019, 228, 801.

111 I. Samarukha, Recycling strategies for End-of-Life Li-ion Batterie from Heavy Electric Vehicles KTH Industrial Engineering and Management, 2020.

112 C. L. Gabriel, Environmental and Natural Resources Engineering, Luleå University of Technology, Finland, 2016.

113 L. L. Gaines and J. B. Dunn, Lithium-Ion Batteries: Advances and Applications, Elsevier, 2014, ch. 21, p. 483.

114 A. Sonoc, J. Jeswiet and V. K. Soo, Procedia CIRP, 2015, 29, 752.

115 T. E. Graedel, J. Allwood, J. P. Birat, B. K. Reck, S. F. Sibley, G. Sonnemann, M. Buchert and C. Hageluken, Nat. Energy, 2019, 4, 253.

116 AReport of Teh Working Group on the Global Metal Flows to the International Resources Panel., United Nations Environment Programme, 2011.

117 D. P. Raphaël, The recycling of lithium-ion batteries $A$ strategic pillar for the European Battery Alliance, Center for Energy, Raphael, 2020.

118 Critical Minerals Today and in 2030: An Analysis for OECD Countries, OECD Environment Working Papers, 2015, No. 91. 